\title{
A Systematic Review of Global Desert Dust and Associated Human Health Effects
}

\author{
Xuelei Zhang ${ }^{1,2, *}$, Lijing Zhao ${ }^{3, *}$, Daniel Q. Tong ${ }^{2,4}$, Guangjian Wu ${ }^{5}$, Mo Dan ${ }^{6}$ and Bo Teng ${ }^{7}$ \\ 1 Key Laboratory of Wetland Ecology and Environment, Northeast Institute of Geography and Agroecology, \\ Chinese Academy of Sciences, Changchun 130102, China \\ 2 Center for Spatial Information Science and Systems, George Mason University, Fairfax, VA 22030, USA \\ 3 Department of Pathophysiology, Norman Bethune Medical School, Jilin University, \\ Changchun 130021, China \\ 4 U.S. NOAA Air Resources Laboratory, College Park, MD 20740, USA; Tongquansong@neigae.ac.cn \\ 5 Key Laboratory of Tibetan Environment Changes and Land Surface Processes, \\ Institute of Tibetan Plateau Research, Chinese Academy of Sciences, Beijing 100101, China; \\ wugj@itpcas.ac.cn \\ 6 Beijing Municipal Institute of Labor Protection, Beijing 100054, China; danmo2001@126.com \\ 7 Department of Otolaryngology Head and Neck Surgery, The Second Hospital, Jilin University, \\ Changchun 130041, China; tengbo1975@163.com \\ * Correspondence: zhangxuelei@neigae.ac.cn (X.Z.); zhao_lj@jlu.edu.cn (L.Z.); \\ Tel.: +86-431-8554-2314 (X.Z.); +86-431-8561-9183 (L.Z.)
}

Academic Editors: Marina Astitha and George Kallos

Received: 28 July 2016; Accepted: 15 November 2016; Published: 6 December 2016

\begin{abstract}
Dust storms and sandy dust events originating in arid and semi-arid areas can transport particulate material, pollutants, and potential transport long distances from their sources. Exposure to desert dust particles is generally acknowledged to endanger human health. However, most studies have examined anthropogenic particulate sources, with few studies considering contributions from natural desert dust. A systematic literature review was undertaken using the ISI Web of Knowledge and PubMed databases with the objective of identifying all studies presenting results on the potential health impact from desert dust particles across the world. This review reveals an imbalance between the areas most exposed to dust and the areas most studied in terms of health effects. Among the human health effects of dust storms are mortality and morbidity, arising from respiratory system, circulatory system, and other diseases. We summarize the quantitative results of current scientific health research and possible pathological mechanisms, and describe some of the many challenges related to understanding health effects from exposures to desert dust particles. Overall, for respiratory and circulatory mortality, both positive and negative associations have been reported for $\mathrm{PM}_{10}$ of desert dust, but only a positive relationship was reported between $\mathrm{PM}_{2.5-10}$ and mortality, and a positive relationship was also reported between $\mathrm{PM}_{2.5}$ and human mortality. Future pathological studies should continue to focus on those mechanisms causing the most harmful effect of desert dust on respiratory and cardiovascular diseases. More attention should also be paid to the association between desert dust and the morbidity of other diseases, such as those affecting the reproductive system and nervous system.
\end{abstract}

Keywords: desert dust; health effects; quantitative analysis; geographical distribution; mortality; morbidity; pathological mechanism

\section{Introduction}

Research on dust emissions from desert regions and their transportation in the atmosphere has increased over the last decade. An important driver of this increased focus stems from recognition of 
the impacts of desert dust on the climate system, air quality, and even human health [1-4]. Desert dust also carries certain amounts of bio-particulates and microorganisms such as pollen, fungi, bacteria, and viruses, as well as related protein and lipid components [5]. The need for a better understanding of the role of desert dust in human health and in making protective policy decisions has led to research into the underlying effects of dust on human mortality and morbidity in recent decades. Much of this work has comprised epidemiological studies addressing the association between dust outbreaks and mortality/morbidity [6-13]. More recently, some review studies have given special attention to the effects of far-traveled desert dust on human health in Asia, Europe, and Africa [14-17]. Goudie [18] reviewed the nature of global desert dust storms (main source areas, frequencies, durations, and particulate contents), but only with a limited, qualitative description of dust effects on various human health disorders.

The dust particles may also emit from other natural sources and anthropogenic activities, such as volcanic eruptions, road emissions, and mining activity, but this review only focuses on desert dust and its effects on human health. The purpose of this review paper is to quantitatively review all the studies on the effect of dust storms on human health across the world, and secondly to review in detail the reported underlying pathological processes behind such disorders. Indeed, there are many pathological mechanisms behind the associations between desert dust and human disorders. Moreover, in some cases, the mechanisms are still poorly understood. Through an in-depth review of the available literature, this study aims to highlight the specific links between desert dust and human health from both geographical and pathologicalviewpoints, and recommends directions for future studies.

This paper is organized as follows. Literature searching and filtration methods are illustrated in Section 2. Section 3 presents the preliminary statements on the geographical distribution of study areas in the published literatures and the basic statistical features of medical studies. Section 4 deals with the mortality induced by direct exposure to coarse and fine dust particles in urban environments. Section 5 deals with the morbidity related to the occurrence of desert dust. The conclusions are presented in Section 6.

\section{Data Sources and Methods}

A systematic search of the literatures was undertaken to identify relevant studies investigating the impact of desert dust on human heath, published between January 1990 and October 2014.

Literature searches were conducted using a combination of two groups of keywords: dust names, as objects; and health effects, as outcomes. The databases used were PubMed, EMBASE, MEDLINE, the ISI Web of Knowledge (Web of Science, which includes the Science Citation Index), and Google Scholar. In searches of the epidemiological literature, the keywords were (("Dust" OR "Dust event" OR "Desert dust" OR "Dust storm" OR "Sand storm" OR "Kosa" OR "Yellow sand") AND ("Health effects" OR "Mortality" OR "Morbidity" OR "Respiratory" OR “Cardiovascular" OR "Cardiopulmonary" OR "Pulmonary" OR "Asthma" OR "Rhinitis" OR "Meningitis" OR "Pregnancy" OR "Visit" OR "Admission" OR "Hospital")). For the pathological literature, the keywords were (("Dust" OR “Dust event" OR “Desert dust" OR “Dust storm" OR "Sand dust") AND ("Vivo" OR "Vitro" OR "Cell" OR "Tissue" OR “Organ" OR "Toxicity" OR "Mice" OR "Murine" OR "Mouse" OR "Rat" OR "Microorganism" OR "Pathogen" OR "Bacteria" OR "Fungi" OR "Pollen" OR "Spore" OR "Virus")) without restrictions on publication type or publication date. The study collection included all published papers until October 2014, so that recent articles in relevant journals were identified.

All papers returned by the search $(N=1813)$ were evaluated. Studies concerning health effects of natural desert dust from epidemiology, pathophysiology, or animal experiments were all included. Highly specialized articles about microorganisms of desert dust were also accepted. Only studies on dust from volcanic or anthropogenic sources (such as mining dust or stone dust) were excluded. In total 103 and 72 individual relevant articles met our inclusion criteria for epidemiological and pathological studies, respectively. 
Table 1. The quantitative results for human mortality effects of desert dust particles with different aerodynamic sizes.

\begin{tabular}{|c|c|c|c|c|c|}
\hline Mortality Causes & Population & PM Fraction & $\%$ Risk per $10 \mu \mathrm{g} / \mathrm{m}^{3}(95 \% \mathrm{CI})$ & Location & Reference \\
\hline TotM & All ages & $\mathrm{PM}_{10}$ & $-1.62(-2.76,-0.415)$ & Taipei, Taiwan, China & [19] \\
\hline TotM & All ages & $\mathrm{PM}_{10}$ & $-1.5(-3.0,0.0)$ & Kuwait & {$[20]$} \\
\hline TotM & All ages & $\mathrm{PM}_{10}$ & $-0.1(-0.6,0.4)$ & Athens, Greece & [21] \\
\hline TotM & All ages & $\mathrm{PM}_{10}$ & $0.0(-3.5,3.6)$ & Emilia-Romagna, Italy & [22] \\
\hline TotM & All ages & $\mathrm{PM}_{10}$ & $0.102(-0.20,0.403)$ & Seoul, Korea & [23]] \\
\hline TotM & & $\mathrm{PM}_{10}$ & $0.13(-1.03,1.30)$ & Cyprus & [13] \\
\hline TotM & All ages & $\mathrm{PM}_{10}$ & $0.15(0.00,0.30)$ & 7 cities of Korea & [24] \\
\hline TotM & All ages & $\mathrm{PM}_{10}$ & $0.17(-0.16,0.53)$ & Seoul, Korea & [6] \\
\hline TotM & All ages & $\mathrm{PM}_{10}$ & $0.17(0.05,0.31)$ & Seoul, Korea & [25] \\
\hline TotM & & $\mathrm{PM}_{10}$ & $0.190(-0.028,0.412)$ & Seoul, Korea & [19] \\
\hline TotM & All ages & $\mathrm{PM}_{10}$ & 0.722 & Taipei, Taiwan, China & [7] \\
\hline TotM & All ages & $\mathrm{PM}_{10}$ & $0.79(0.12,1.45)$ & Taipei, Taiwan, China & [26] \\
\hline TotM & All ages & $\mathrm{PM}_{10}$ & $1.16(-1.09,3.63)$ & Kitakyushu, Japan & [19] \\
\hline TotM & & $\mathrm{PM}_{10}$ & $1.70(0.79,2.62)$ & Madrid, Spain & [27] \\
\hline TotM & All ages & $\mathrm{PM}_{10}$ & $1.96(0.38,3.78)$ & Sydney, Australia & [28] \\
\hline TotM & Age $>75$ & $\mathrm{PM}_{10}$ & $2.7(1.4,4.1)$ & Madrid, Spain & [29] \\
\hline TotM & Age $>35$ & $\mathrm{PM}_{10}$ & $3.0(0.0,6.0)$ & Rome, Italy & [11] \\
\hline TotM & All ages & $\mathrm{PM}_{2.5}$ & $0.3(0.1,0.5)$ & Seoul, Korea & [30] \\
\hline TotM & Age $>35$ & $\mathrm{PM}_{2.5}$ & $2.5(-0.9,6.1)$ & Rome, Italy & [11] \\
\hline TotM & All ages & $\mathrm{PM}_{2.5}$ & $2.9(-1.1,6.9)$ & Madrid, Spain & [31] \\
\hline TotM & All ages & $\mathrm{PM}_{2.5}$ & $5.0(0.5,9.7)$ & Barcelona, Spain & [10] \\
\hline TotM & Age $>35$ & $\mathrm{PM}_{2.5-10}$ & $1.1(-0.6,2.7)$ & Rome, Italy & [11] \\
\hline TotM & All ages & $\mathrm{PM}_{2.5-10}$ & $2.8(0.1,5.8)$ & Madrid, Spain & [31] \\
\hline TotM & All ages & $\mathrm{PM}_{2.5-10}$ & $8.4(1.5,15.8)$ & Barcelona, Spain & {$[10]$} \\
\hline
\end{tabular}


Table 1. Cont

\begin{tabular}{|c|c|c|c|c|c|}
\hline Mortality Causes & Population & PM Fraction & $\%$ Risk per $10 \mu \mathrm{g} / \mathrm{m}^{3}(95 \% \mathrm{CI})$ & Location & Reference \\
\hline RES & $\mathrm{PM}_{10}$ & & $-5.31(-8.64,-1.71)$ & Taipei, Taiwan, China & [19] \\
\hline RES & & $\mathrm{PM}_{10}$ & $-4.0(-1.2,4.0)$ & Kuwait & [20] \\
\hline RES & All ages & $\mathrm{PM}_{10}$ & $-0.2(-10.8,11.5)$ & Emilia-Romagna, Italy & [22] \\
\hline RES & All ages & $\mathrm{PM}_{10}$ & $0.2(-0.5,2.7)$ & Athens, Greece & [21] \\
\hline RES & All ages & $\mathrm{PM}_{10}$ & $0.25(-0.33,0.86)$ & 7 cities of Korea & [24] \\
\hline RES & & $\mathrm{PM}_{10}$ & $0.79(-4.69,3.28)$ & Cyprus & [13] \\
\hline RES & All ages & $\mathrm{PM}_{10}$ & $1.49(0.03,3.47)$ & Seoul, Korea & [23] \\
\hline RES & Age $>35$ & $\mathrm{PM}_{10}$ & $2.5(-11.9,19.3)$ & Rome, Italy & [11] \\
\hline RES & All ages & $\mathrm{PM}_{10}$ & $2.91(-4.18,3.04)$ & Sydney, Australia & [28] \\
\hline RES & & $\mathrm{PM}_{10}$ & $3.48(1.22,5.79)$ & Madrid, Spain & [27] \\
\hline RES & Age $>75$ & $\mathrm{PM}_{10}$ & $4.0(1.7,6.3)$ & Madrid, Spain & [29] \\
\hline RES & & $\mathrm{PM}_{10}$ & $0.637(-0.222,1.572)$ & Seoul, Korea & [19] \\
\hline RES & All ages & $\mathrm{PM}_{10}$ & 7.66 & Taipei, Taiwan, China & [7] \\
\hline RES & & $\mathrm{PM}_{10}$ & $6.27(0.50,13.03)$ & Kitakyushu, Japan & [19] \\
\hline RES & All ages & $\mathrm{PM}_{2.5-10}$ & $3.51(-8.19,16.60)$ & Barcelona, Spain & [10] \\
\hline RES & Age $>35$ & $\mathrm{PM}_{2.5-10}$ & $9.8(0.2,21.3)$ & Rome, Italy & [11] \\
\hline RES & Age $>35$ & $\mathrm{PM}_{2.5}$ & $6.6(-10,27)$ & Rome, Italy & [11] \\
\hline RES & All ages & $\mathrm{PM}_{2.5-1}$ & $15.71(-2.43,36.29)$ & Barcelona, Spain & [10] \\
\hline RES & All ages & $\mathrm{PM}_{1}$ & $1.95(-9.20,14.37)$ & Barcelona, Spain & [10] \\
\hline CIRC & & $\mathrm{PM}_{10}$ & 0.30 & Kermanshah, Iran & [32] \\
\hline CIRC & Age $>65$ & $\mathrm{PM}_{10}$ & $0.6(0.1,1.1)$ & Western Japan & [33] \\
\hline CIRC & & $\mathrm{PM}_{10}$ & $1.95(0.29,3.64)$ & Madrid, Spain & {$[27]$} \\
\hline CIRC & All ages & $\mathrm{PM}_{10}$ & $2.59 \%$ & Taipei, Taiwan, China & [7] \\
\hline CIRC & Age $>75$ & $\mathrm{PM}_{10}$ & $3.5(0.9,6.1)$ & Madrid, Spain & [29] \\
\hline CIRC & Age $>35$ & $\mathrm{PM}_{10}$ & $5.5(0.9,10.2)$ & Rome, Italy & [11] \\
\hline CIRC & Age $>35$ & $\mathrm{PM}_{2.5}$ & $-0.7(-5.5,4.4)$ & Rome, Italy & [11] \\
\hline CIRC & & $\mathrm{PM}_{2.5}$ & $2.5(0.7,4.5)$ & Madrid, Spain & [34] \\
\hline CIRC & Age $>35$ & $\mathrm{PM}_{2.5-10}$ & $4.0(1.6,6.5)$ & Rome, Italy & {$[11]$} \\
\hline
\end{tabular}


Table 1. Cont

\begin{tabular}{|c|c|c|c|c|c|}
\hline Mortality Causes & Population & PM Fraction & $\%$ Risk per $10 \mu \mathrm{g} / \mathrm{m}^{3}(95 \% \mathrm{CI})$ & Location & Reference \\
\hline CAR & & $\mathrm{PM}_{10}$ & $-1.83(-4.09,0.55)$ & Taipei, Taiwan, China & [19] \\
\hline CAR & & $\mathrm{PM}_{10}$ & $-1.4(-4.0,1.2)$ & Kuwait & [20] \\
\hline CAR & All ages & $\mathrm{PM}_{10}$ & $-0.8(-5.9,4.6)$ & Emilia-Romagna, Italy & [22] \\
\hline CAR & All ages & $\mathrm{PM}_{10}$ & $-0.25(-0.80,0.40)$ & Seoul, Korea & [23] \\
\hline CAR & All ages & $\mathrm{PM}_{10}$ & $0.2(-0.4,0.9)$ & Athens, Greece & [21] \\
\hline CAR & & $\mathrm{PM}_{10}$ & 0.30 & Kermanshah, Iran & [32] \\
\hline CAR & All ages & $\mathrm{PM}_{10}$ & $0.30(0.01,0.59)$ & 7 cities of Korea & [24] \\
\hline CAR & & $\mathrm{PM}_{10}$ & $0.408(-0.003,0.837)$ & Seoul, Korea & [19] \\
\hline CAR \& RES & All ages & $\mathrm{PM}_{10}$ & $0.41(-0.38,1.26)$ & Seoul, Korea & [6] \\
\hline CAR & All ages & $\mathrm{PM}_{10}$ & $1.52(-1.65,5.57)$ & Sydney, Australia & [28] \\
\hline CAR & & $\mathrm{PM}_{10}$ & $2.43(0.53,4.37)$ & Cyprus & [13] \\
\hline CAR & & $\mathrm{PM}_{10}$ & $4.09(0.006,8.73)$ & Kitakyushu, Japan & [19] \\
\hline CAR & Age $>35$ & $\mathrm{PM}_{10}$ & $8.9(3.5,14.5)$ & Rome, Italy & [11] \\
\hline CAR & Age $>35$ & $\mathrm{PM}_{2.5-10}$ & $4.9(2.2,7.8)$ & Rome, Italy & [11] \\
\hline CAR & All ages & $\mathrm{PM}_{2.5-10}$ & $10.32(3.09,17.98)$ & Barcelona, Spain & [10] \\
\hline CAR & All ages & $\mathrm{PM}_{2.5}$ & $0.2(-0.1,0.5)$ & Seoul, Korea & [30] \\
\hline CAR & Age $>35$ & $\mathrm{PM}_{2.5}$ & $1.1(-4.6,7.2)$ & Rome, Italy & [11] \\
\hline CAR & All ages & $\mathrm{PM}_{2.5-1}$ & $13.29(2.57,24.71)$ & Barcelona, Spain & [10] \\
\hline CAR & All ages & $\mathrm{PM}_{1}$ & $4.14(-3.22,12.07)$ & Barcelona, Spain & [10] \\
\hline CER & Age $>35$ & $\mathrm{PM}_{10}$ & $1.6(-4.7,8.4)$ & Rome, Italy & [11] \\
\hline CER & & $\mathrm{PM}_{10}$ & $0.46(-2.93,3.96)$ & Madrid, Spain & [27] \\
\hline CER & Age $>35$ & $\mathrm{PM}_{2.5}$ & $-2.5(-9.1,4.8)$ & Rome, Italy & [11] \\
\hline CER & All ages & $\mathrm{PM}_{2.5-10}$ & $8.62(4.36,23.30)$ & Barcelona, Spain & [10] \\
\hline CER & Age $>35$ & $\mathrm{PM}_{2.5-10}$ & $3.5(0.6,6.7)$ & Barcelona, Spain & [10] \\
\hline CER & All ages & $\mathrm{PM}_{2.5-1}$ & $0.29(18.43,21.86)$ & Barcelona, Spain & [10] \\
\hline CER & All ages & $\mathrm{PM}_{1}$ & $5.29(-8.16,20.46)$ & Barcelona, Spain & [10] \\
\hline
\end{tabular}

TotM: Total Mortality; RES: Respiratory Mortality; CIRC: Circulatory Mortality; CAR: Cardiovascular Mortality; CER: Cerebrovascular Mortality. 
A preliminary qualitative investigation of the 103 epidemiological studies allowed us to summarize each study by identifying various parameters. We determined the study area, dust origin, study period, health effects, target population, analysis methods, identification methods of dust events, and the main results (details in Table S1 (Sheet 1) of the supplementary Excel file). For epidemiological studies with quantitative results for desert dust effects on human mortality, the risk factors and associated $95 \%$ confidence interval were also extracted and tabulated (Table 1).

The reference lists of the identified 175 publications are analyzed and discussed in the successive sections. Firstly, once studies were classified according to the types of relationship between dust and health effects (primarily divided into mortality and morbidity), we reviewed the geographic distribution of study areas. Then, we looked at potential associations between publication date and dust origin. The next section explores specific health effects from natural desert dust. Furthermore, the pathological mechanisms and toxicity of desert dust in cell and animal experiments were also reviewed. Finally, in the light of the previous discussions, the last section provides recommendations for future work.

\section{Preliminary Statements}

\subsection{Geographical Distribution of Studies Addressing Health Effects of Desert Dust}

The health effects of desert dust will depend on where human populations are located with respect to dust storms and subsequent dust transport trajectories [18]. Based on the observations from different satellites and on the output of numerical models [35-40], the desert, Gobi and arid areas are identified as the primary dust sources. Also, many sources are associated with alluvial deposits or piedmont alluvial fans [41,42]. Estimates of the relative strengths of dust emissions from different parts of the world show varying contributions: firstly is the Sahara (more than $50 \%$ ), secondly Central and East Asia (with about 20\%), thirdly the Middle East, and fourthly Australia. Southern Africa and the Americas are relatively minor sources, together accounting for less than $5 \%$ of the global total dust emissions [37].

The locations of reported study areas (red points in Figure 1) with reference to dust health effects, combined with satellite-monitored global dust emission sources, are depicted in Figure 1. The geographical distribution of the 103 articles includes contributions mainly from 27 countries or areas, such as those in Asia (China, Japan, South Korea, India, Uzbekistan, Iran, Israel, Kuwait); Europe (Spain, Italy, Greece, Cyprus); Africa (Canary Island, Mali, Burkina Faso, Niger); and elsewhere (Australia, Canada, the USA, the Caribbean, and Puerto Rico).

The distribution of global dust sources reveals a dominant dust source belt located in the mid-latitudes $\left(15^{\circ} \mathrm{N}-45^{\circ} \mathrm{N}\right)$ of the northern hemisphere [36], which we further divided into regional dust sources such as Asian dust, Saharan dust, Australian dust, and others. Asian dust is by far the most frequently studied in the literature (64 papers, or $62.1 \%$, of all included studies), and most studies focus on health effects in Asian countries/areas (97\%), with only two papers studying the health effects of long-distance transported dust across the Pacific to central western North America (one is from Canada and another is from the USA). Saharan dust is the second most frequently studied source in the last five years (33 papers, 32.1\% of total included studies), and these studies mostly focus on health effects in European (Spain, Italy, Greece, and Cyprus), western Asian (Iran, Israel, and Kuwait) and African (Burkina Faso, Mali, Niger, and the Canary Islands) countries/areas close to the Sahara desert $(90.6 \%)$; only four papers studied the health effects of intercontinental transported dust across the Atlantic to the Caribbean area of Central America (one from Trinidad, another two from Barbados and Grenada, and one from Puerto Rico). Other dust sources (Australian dust and North American dust, 6 papers, $5.8 \%$ of total included studies) are also explored but, despite the presence of important dust sources over southern South America, no study dealing with dust's impact on health in South America has been published. 


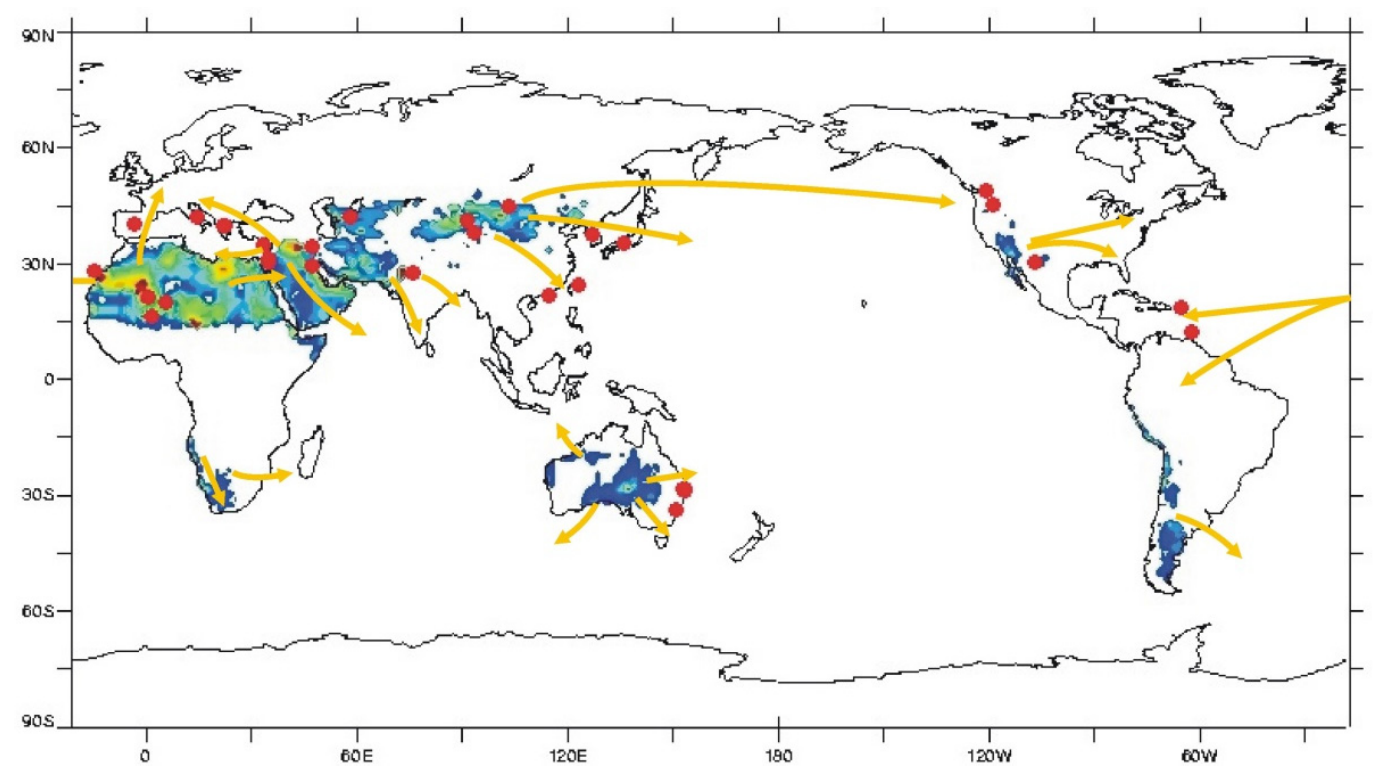

Figure 1. The geographical distribution of the linkage between dust sources and epidemical study areas (red points: locations of reported effects of desert dust on human health; color-filled contour: distribution of dust sources).

Just as wind-blown dust emitted from dust sources could be transported over long distances to other areas, desert dust could also impact on the health of residents living in downwind regions. Asian dust may reach North America and Europe via the Pacific [43]. Saharan dust could be carried thousands of kilometers to the Mediterranean [44], Europe [45,46], the Middle East [9,47], the Americas [48], and even the Arctic [49]. The above trajectories can be seen during specific times of the year, with the intensity varying annually [50]. Overall, $60 \%$ of total Saharan dust particles are blown southwards across the West African states [51-53] into the Gulf of Guinea [54] and across the Atlantic [55] to the Central Americas [56], where their health implications have been explored in such countries as Trinidad, Barbados, Grenada, and Puerto Rico. The Sahara is also a major source of dust deposition into the Mediterranean Sea and neighboring countries [57,58].

\subsection{Desert Dust-Related Health Diseases}

Pathological studies are strongly geographically biased towards certain desert dust sources. Some $75 \%$ of published papers $(N=54)$ focused on the Asian dust, $14 \%$ of published papers $(N=10)$ were carried out on desert dust from North America, and only 7\% $(N=5)$ and $4 \%(N=3)$ of the selected studies focused on Middle Eastern dust and Saharan dust, respectively.

Of the 103 epidemiological studies included in our review (Table S2 (Sheet 1) in the supplementary Excel file), 26 and 77 were published before and after the year 2008, respectively, indicating that in recent years there has been increasing interest in the epidemiologic health effects of desert dust (Figure 2a). In general, these epidemiologic studies investigated changes in mortality or morbidity before, during, and after dust storm events or compared health effects in populations between control days and dust days. 

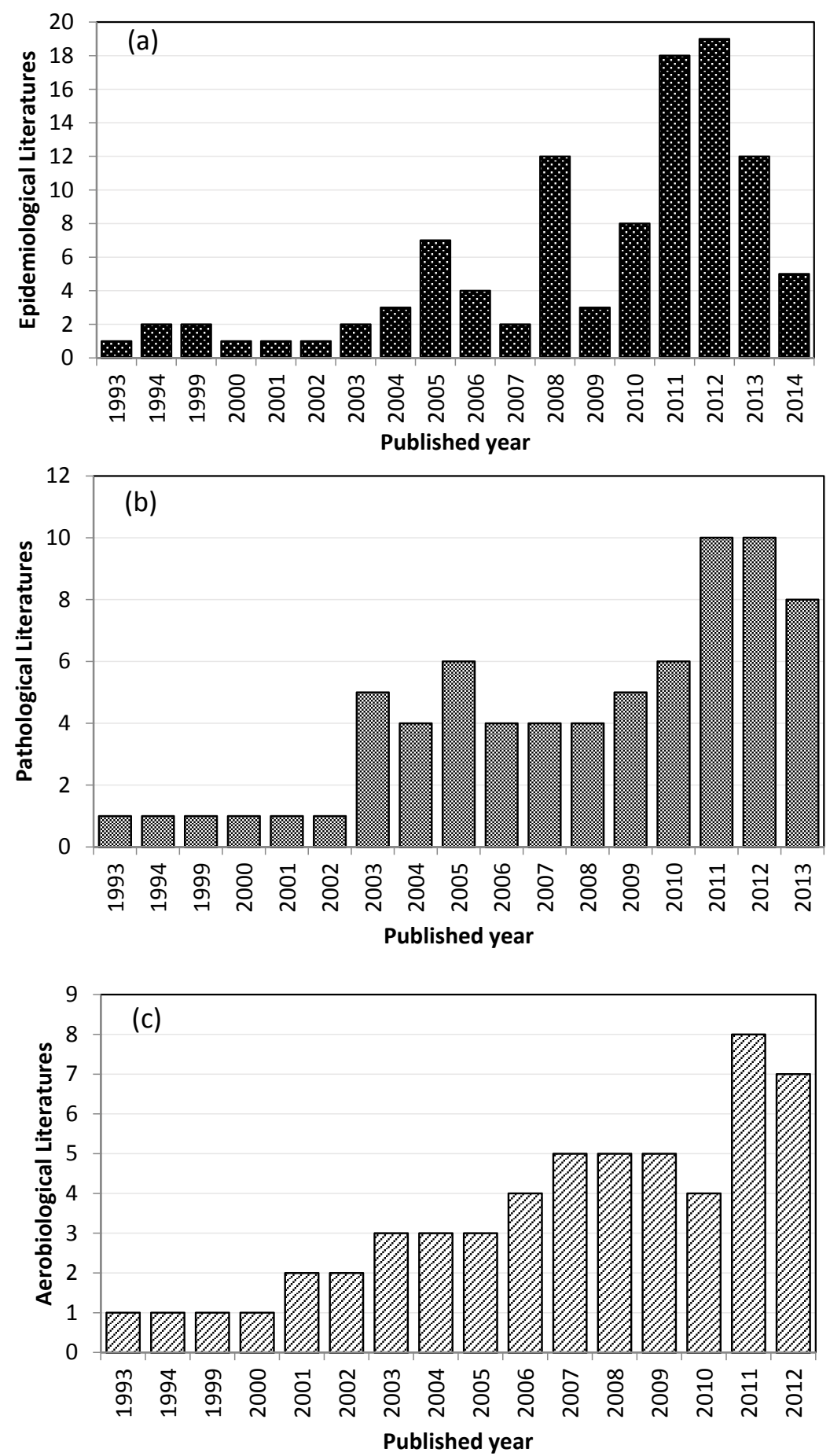

Figure 2. Number of published articles related desert dust to human health for (a) epidemiology; (b) pathology; and (c) airborne microorganisms.

The causes of mortality examined in included studies are classified following the International Classification of Diseases, version 9 (ICD-9) [59] or version 10 (ICD-10) [60]. All natural causes or total causes without accidents (ICD-9 codes 1-799 or ICD-10 codes A00-R99), circulatory system causes (ICD-9 codes 390-459 or ICD-10 codes I00-I99), and respiratory system causes (ICD-9 codes 460-519 or ICD-10 codes J00-J99) are analyzed in Table 1 . Within the circulatory system group, deaths specifically due to cardiovascular causes (ICD-9 codes 390-429 or ICD-10 codes I00-I52) and cerebrovascular causes (ICD-9 codes 430-438 or ICD-10 codes I60-I69) were also analyzed. 
A number of adverse health effects, including injuries and death from transport accidents, non-accidental death, respiratory diseases (rhinitis, asthma, tracheitis, pneumonia, coccidiomycosis), cardiovascular diseases (stroke, arrhythmia, ischemic heart disease, cerebrovascular disease), cardiopulmonary diseases (chronic obstructive pulmonary disease, COPD), and, more rarely, conjunctivitis, meningococcal meningitis, dermatological disorders, skin allergy, and exacerbated cough are associated with desert dust (Figure 3). A generalized additive model (GAM) with nonlinear Poisson regression is widely used as a flexible and effective technique to analyze data in time-series and case-crossover studies of the health effects of desert dust. GAM uses a link function to establish a relationship between the mean of the response variable and a smoothed function of the explanatory variables [61]. In typical Poisson regression analyses, person-time and events are tabulated by categorizing predictor variables that were originally measured on a continuous scale [62]. In most studies of desert dust impacts on excess deaths/hospital admissions/emergency visits, a distinction is always made between cases of mortality/morbidity due to 'all causes', cases due to respiratory diseases, and cases due to cardiovascular diseases. Of the 72 pathological studies included in our review (Table S2 in the supplementary file), 25 and 47 were published before and after the year 2008, respectively, indicating that, in recent years, there has also been increasing interest in the pathological health effects of desert dust (Figure 2b). Furthermore, $51 \%$ of published papers $(N=37)$ were conducted in vivo using animal experiments, of which the dominant target animals were mice and sheep; the other $49 \%$ of published papers $(N=35)$ were conducted in vitro using cell cultures, in which the primary targets were epithelial cells in the airway.

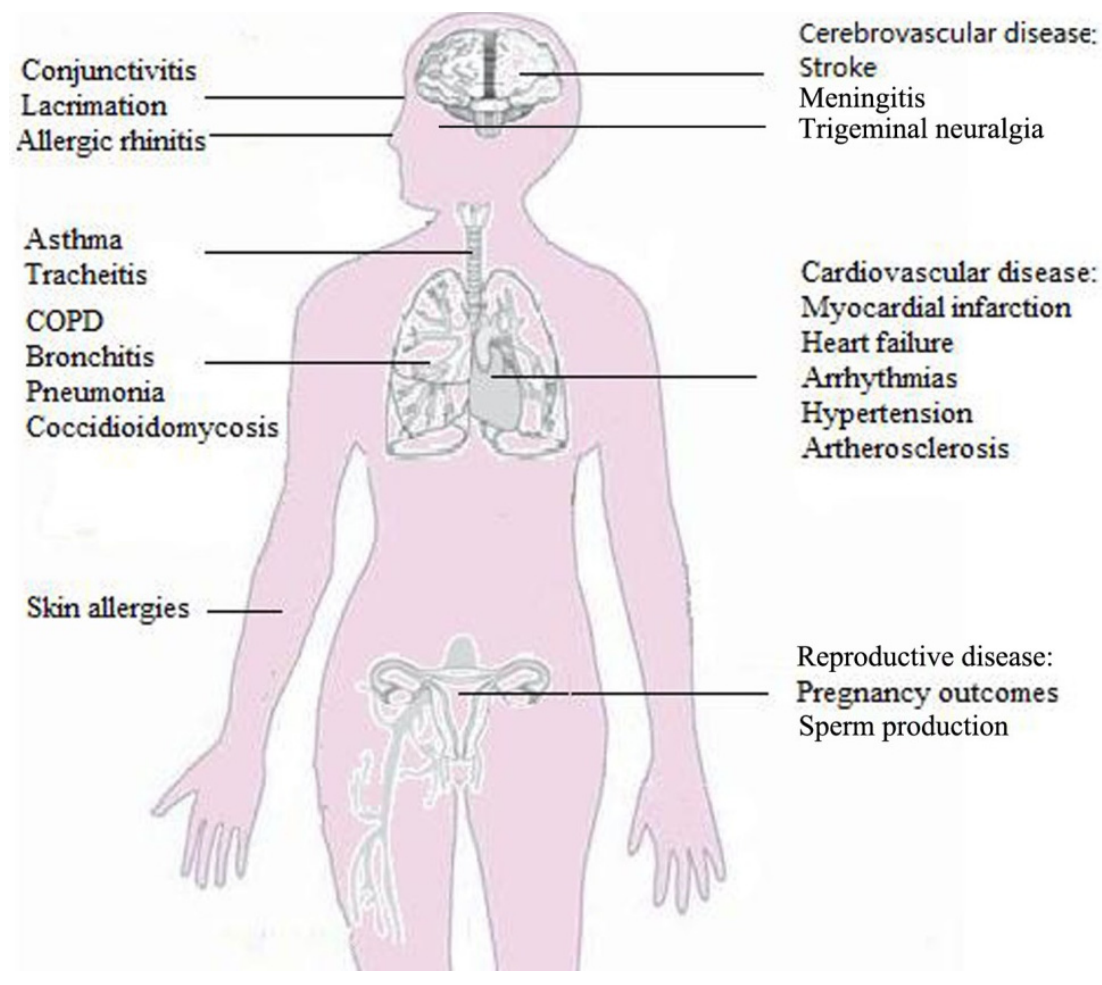

Figure 3. Schematic drawing of desert dust-related human diseases in different organs.

Griffin et al. [63] have systematically reviewed desert dust microbiology and its health effects up to the year 2007, and Gonzalez-Martin et al. [5] have reviewed the sampling and microbial identification methods for global dispersion of pathogenic microorganisms by dust storms. There is not space in this paper to consider in detail the specific pathogens and related diseases, or even the possible mechanisms. In order to avoid duplication, we review the geographical and temporal distribution of related microbiological studies in this section. All general identified microbiology studies related 
to dust storms are listed in Table S3 in the supplementary file. Of a total 54 studies matching our searching conditions described in Section 2, 74\% $(N=40), 46 \%(N=25), 4 \%(N=2)$, and $4 \%(N=2)$ of the total aerobiological literatures related to airborne desert dust are targeted on bacteria, fungi, pollen, and viruses, respectively. In terms of temporal distribution, 17 and 37 studies were published before and after the year 2008, respectively (Figure 2c). Recent studies are increasingly focused on the airborne bacterial community transported with the Asian and Middle East dusts after the year 2008. Further long-term studies with a broader domain considering local and transported airborne microorganisms will provide valuable perspective for the fields of environment and public health.

\section{Desert Dust and Human Mortality}

Although more detailed knowledge is needed about the effect of Saharan dust on mortality, what has been thoroughly documented is the fact that exposure to atmospheric particulate matter causes premature mortality $[10,21,29,64]$.

There is increasing evidence of all-cause and specific mortalities associated with dust events. All studies could be sorted into two categories based on the study method. A number of studies use regression models constructed for days with desert dust intrusions and for control days when no dust event was observed, and many other studies concerning desert dust health effects use case-crossover designs or time-series analysis. Table 1 provides an overview of the global studies that quantitatively investigate the mortality effects of desert dust particles with different aerodynamic sizes. Estimated effects are reported as percentage increases in risk of death (IR\%), and $95 \%$ confidence intervals $(95 \% \mathrm{CI})$ associated with an increase of $10 \mu \mathrm{g} / \mathrm{m}^{3}$ in the PM fractions. A total of 27 studies reported the quantitative estimations of mortality effects due to exposure to desert dust, and three studies were excluded due to their qualitative descriptions that confirm the association between human mortality and desert dust or deficiency of dust concentration for convert to $10 \mu \mathrm{g} / \mathrm{m}^{3}$ increases $[29,65,66]$. The specific age groups (above 75 years, above 65 years, or above 35 yeas) or all ages for epidemiological analysis are also listed in Table 1.

\subsection{Mortality Effects from Desert Dust Coarse Particles, $P M_{10}$ and $P M_{2.5-10}$}

Nineteen studies consider the mortality effects of coarse dust particles ( $\mathrm{PM}_{10}$ and $\left.\mathrm{PM}_{2.5-10}\right)$. As shown in Table 1, most of these focus on the association between human mortality and $\mathrm{PM}_{10}$ during dust events over 18 cities/areas in 10 countries, and only two studies considered the mortality effects of the $\mathrm{PM}_{2.5-10}$ fraction of transported dust to two cities in the Mediterranean (Rome and Barcelona).

The results of 14 studies investigating the associations between exposures to $\mathrm{PM}_{10}$ particles and total mortality are not in agreement. Ten of the published studies state that $\mathrm{PM}_{10}$ particles present during dust days increase total mortality, while the other four studies find no association between mortality and $\mathrm{PM}_{10}$. Recently, Samoli et al. [21] and Sajani et al. [22] in Athens (Greece) and Emilia Romagna (Italy) found no evidence of any effect of dust events on the relationship between $\mathrm{PM}_{10}$ and daily mortality. Similarly, two recent studies conducted in Kuwait and Taipei (Taiwan) also report stronger negative associations between $\mathrm{PM}_{10}$ and all-cause mortality $[19,20]$, supporting the viewpoint that desert dust comprising natural crustal materials is less toxic than that comprising anthropic particles. Meta-analysis of all the reported quantitative results reveals a pooled random effect of $0.27 \%$ (95\% CI: 0.05\%-0.49\%).

Only three European studies reported a positive association between $\mathrm{PM}_{2.5-10}$ fraction and daily mortality. On the contrary, Jiménez et al. [29] concluded that the $\mathrm{PM}_{2.5-10}$ fraction did not cause any significant effect on daily mortality in Madrid. Pérez et al. [10] showed that coarse particles during Saharan dust days significantly increased (by 8.4\%) daily mortality in Barcelona, Spain. Tobías et al. [31] and Mallone et al. [11] reported lower mortality effects of coarse particles $\mathrm{PM}_{2.5-10}$ with $2.8 \%$ and $1.1 \%$ increases, respectively, during desert dust episodes for all-cause mortality.

For specific mortality, nine studies revealed positive relationships between $\mathrm{PM}_{10}$ and respiratory mortality, but another three studies demonstrated a negative relationship. Three studies reporting the 
negative relationship for respiratory mortality are the same as those reporting the total mortality $[19,20,22]$. An exceptional study reported positive relationship for respiratory mortality but negative relationship for total mortality in Athens [21]. In addition, Pérez et al. [67] and Mallone et al. [11] showed that an increase of $10 \mu \mathrm{g} / \mathrm{m}^{3}$ of $\mathrm{PM}_{2.5-10}$ increased respiratory mortality by $3.5 \%$ and $9.8 \%$ compared to non-dust days in Barcelona (Spain) and Rome (Italy), respectively.

All six relevant studies demonstrated circulatory mortality associated with $\mathrm{PM}_{10}$ concentrations of dust events. In Taiwan, Chen et al. [68] estimated that the $\mathrm{PM}_{10}$ effect during Asian dust days was positive for circulatory mortality, with an increase of $0.38 \%$. In other Asian countries, Kashima et al. [33] and Delangizan and Jafari [32] reported $0.6 \%$ and $0.3 \%$ excess circulatory deaths due to exposure to $\mathrm{PM}_{10}$ during dust events in Western Japan and Iran. The study of Díaz et al. [27] conducted in Madrid (Spain) found that Saharan dust storms were associated with a 1.95\% increase in circulatory mortality among all ages in Madrid based on an increase of $10 \mu \mathrm{g} / \mathrm{m}^{3}$ in daily mean $\mathrm{PM}_{10}$. Another study conducted in the same region (Madrid, Spain) reports that the risk increased by $4.0 \%$ among subjects aged over 75 years [29], implying that elderly subjects are most susceptible to suffering from the circulatory mortality effects of suspended dust particulates; this is due to deterioration of their general health in the ageing process. Only Mallone et al. [11] reported strong and statistically significant association between $10 \mu \mathrm{g} / \mathrm{m}^{3}$ increasing of $\mathrm{PM}_{2.5-10}$ and circulatory mortality during dust-affected days (7.34\%; 95\% CI: $2.96 \%-11.93 \%$ ) in Rome (Italy).

When further dividing circulatory mortality into cardiovascular mortality (12 studies) and cerebrovascular mortality (three studies), the results for $\mathrm{PM}_{10}$ are still not in agreement. Although eight studies revealed a positive relationship between $\mathrm{PM}_{10}$ and cardiovascular mortality, four other studies demonstrated a negative relationship. Two studies demonstrated a positive association between $\mathrm{PM}_{10}$ and cerebrovascular mortality, but the other study [11] reported a strong and statistically significant negative association between them $(-2.52 \%$; $95 \% \mathrm{CI}:-9.16 \%-4.77 \%)$. Both European studies indicated stronger and statistically significant association between each $10 \mu \mathrm{g} / \mathrm{m}^{3}$ increase of $\mathrm{PM}_{2.5-10}$ and both cardiovascular and cerebrovascular mortalities during dust-affected days in Europe [10,11].

\subsection{Mortality Effects of Desert Dust Fine/Ultrafine Particles, $P M_{2.5}, P M_{2.5-1}$, and $P M_{1.0}$}

Only seven works report on the mortality effects of the fine and ultrafine fractions of the desert dust (Table 1). All studies yielded similar results, whereby the association of $\mathrm{PM}_{2.5}$ fraction with total or cause-specific mortality was positive but not statistically significant. In Barcelona (Spain), a daily increase of $10 \mu \mathrm{g} / \mathrm{m}^{3}$ in $\mathrm{PM}_{2.5}$ increased daily mortality by $5.0 \%$ (95\% CI: 0.5\%-9.7\%) with no statistical significance during Saharan dust days [10]. However, a recent study conducted in Madrid (Spain) reports that total mortality effects of $\mathrm{PM}_{2.5}$ were similar during days with and without Saharan dust (2.9\% and $2.6 \%$ risk, respectively) [31]. The study of Maté et al. [34] confirmed statistically significant associations between daily mean $\mathrm{PM}_{2.5}$ concentrations and short-term overall circulatory mortality and acute myocardial infarction mortality in the city of Madrid, but no statistically significant association was found with other ischemic heart diseases or with cerebrovascular diseases. In Seoul (Korea), during Asian dust days when the $\mathrm{PM}_{2.5}$ concentration was lower than that during smog days, the relative risks of exposure to $\mathrm{PM}_{2.5}$ for both all-cause and cardiovascular mortalities were higher than those for smog days, and a non-significant association between $\mathrm{PM}_{2.5}$ and respiratory deaths was found during dust event days [30]. This may indicate that not only the $\mathrm{PM}_{2.5}$ mass, but also the particular constituents of $\mathrm{PM}_{2.5}$ during specific events, may play an important role in adverse health outcomes.

By contrast, Mallone et al. [11] also found that $\mathrm{PM}_{2.5}$ effect estimates during Saharan dust days were negative for circulatory and cerebrovascular mortality in Rome (Italy). Furthermore, the study of Jiménez et al. [29] conducted in Madrid (Spain) also found that the daily mean $\mathrm{PM}_{2.5}$ concentrations displayed a significant statistical association with daily mortality for total mortality, circulatory, and respiratory causes on non-Saharan dust days, while this association was absent for Saharan dust days.

Only one published study has investigated the mortality effects of $\mathrm{PM}_{2.5-1}$ and $\mathrm{PM}_{1}$ fractions during Saharan dust intrusions into southern Europe (Barcelona, Spain) [10]. Although the estimated 
effect of $\mathrm{PM}_{2.5-1.0}$ during Saharan dust days was marginally significant $(p<0.1)$, the risk was about twice as large as that during non-Saharan dust days for cardiovascular mortality at lag 1 and respiratory mortality at lag 2 (13.29\%, 95\% CI: $2.57 \%-24.71 \%$ and $15.71 \%, 95 \%$ CI: $-2.43 \%-36.29 \%$, respectively). The authors also found that the effects of short-term exposure to $\mathrm{PM}_{1.0}$ originated almost entirely from traffic-related combustion sources in Barcelona and did not change during Saharan dust days. In general, long-distance transport reduces the number of heavier and larger particles in Saharan air masses, thus increasing the relative contribution of smaller particles. The results show that $\mathrm{PM}_{2.5-10}$ (the usual definition of the coarse fraction adopted in air pollution monitoring and in epidemiological studies) should be employed with caution as a specific marker of Saharan dust transport, which is probably better described by $\mathrm{PM}_{1-10}[22,67]$.

Overall, both positive and negative associations have been reported for $\mathrm{PM}_{10}$, but only a positive relationship was reported between $\mathrm{PM}_{2.5-10}$ and mortality. Positive relationships were also reported between $\mathrm{PM}_{2.5}$ and mortality, except for Mallone et al. [11]. The plausible explanation for the presence of both positive and negative relationships is that different epidemiological studies were carried out in different locations at varying distances from the desert sources, with different exposure concentrations; furthermore, trajectories can vary between source areas and the study areas, and different sources emit different chemical components. Moreover, the toxicological properties of the desert dust particles might be modified by mixing with anthropogenic emissions from industrial regions during different transport paths $[19,69]$.

\section{Desert Dust and Human Morbidity}

\subsection{Desert Dust and Respiratory Disease}

Airborne dust particles are transported via air inhaled through the nose or mouth, and passed via the trachea to the lung tissues. The respiratory system may be divided into three regions (nasopharyngeal region, tracheobronchial region, and bottom lung tissue region) and particle size deposition roughly correlates with diseases in these regions [70]. A related diagram of the human respiratory system is shown in Figure 4.

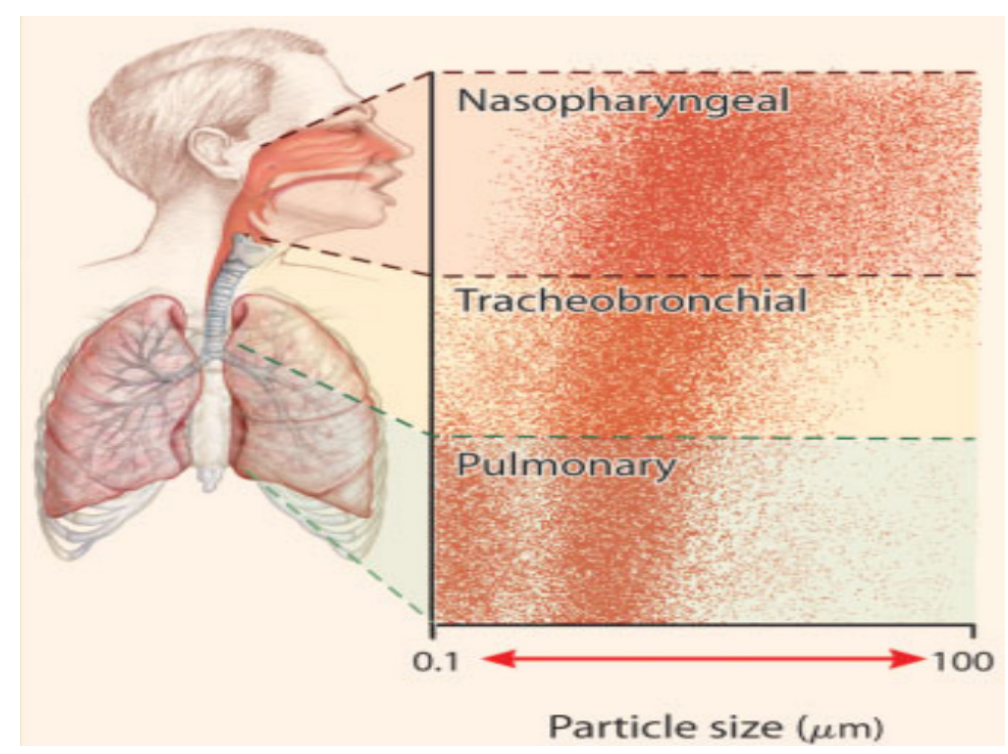

Figure 4. A schematic diagram dividing the respiratory system into three regions (nasopharyngeal region, tracheobronchial region, and pulmonary region) with possible penetrated particle sizes. Authorized copy from [71]. 


\subsubsection{Desert Dust Associated with Asthma and Rhinitis}

Asthma is a chronic inflammatory airway condition characterized by repetitive wheezing, coughing, and shortness of breath secondary to reversible airflow limitations. The incidence of allergic asthma has increased steadily globally. In many parts of the world, sand storms have been linked to asthma exacerbation. Prospero et al. [72] reported on a two-year retrospective study of daily pediatric asthma admissions in Barbados in relation to daily concentrations of transported dust. In Trinidad, Saharan dust was also linked to pediatric asthma exacerbation [73]. The $\mathrm{PM}_{10}$ and $\mathrm{PM}_{2.5-10}$ pollutants contained in the Saharan dust increased the risk of visiting the health emergency department by $9.1 \%$ and $4.5 \%$, respectively, for children with asthma in Guadeloupe [74]. Meo et al. [75] reported the effect of sandstorms on acute asthma attacks in volunteers in Riyadh, Saudi Arabia; they found that subjects exposed to sandstorms developed asthma and that the prevalence was prominent in $20.9 \%$ of cases. Thalib and Al-Taiar [76] investigated the impact of dust storms on daily emergency asthma admissions, finding an $8.4 \%$ increase over a period of five years in Kuwait, which was particularly evident among children. In Australia, a number of dust events were significantly associated with changes in asthma severity, but general relationships could not be determined [77]. The September 2009 dust storm in Sydney, Australia was significantly associated with a $23.0 \%$ increase in asthma-related emergency department presentations and a $14.1 \%$ increase of asthma hospital admissions compared to non-dust periods [78]. In Athens, Greece, Saharan dust events have been associated with a $2.54 \%$ increase of pediatric asthma hospital admissions based on a $10 \mu \mathrm{g} / \mathrm{m}^{3}$ increase in $\mathrm{PM}_{10}$ [79]. People of all ages in El Paso of Texas were 1.11 times more likely to be hospitalized by asthma on a dust event day than on a clear day [80]. Bell et al. [81] investigated the relationship between cause-specific hospital admissions and sandstorms in Taipei, and that found asthma admissions rose $4.48 \%$ per $28 \mu \mathrm{g} / \mathrm{m}^{3}$ increase in $\mathrm{PM}_{10}$ levels. The estimated relative risk for asthma admission was 1.07 (95\% CI: 1.05-1.10) on dust days in seven metropolitan districts in Korea [82]. The estimated percentage increase in the rate of asthma treatments after the dust event, using 4-6-day moving means, was about 18\% in Seoul, Korea [83]. Kanatani et al. [84] reported a statistically significant association between child asthma hospitalization and a heavy dust event in Toyama, Japan, and the crude odds ratio (OR) of the heavy dust event for hospitalization on the day was $1.88(P=0.037)$. Wantanabe [85] reported that $11 \%-22 \%$ of patients with asthma experienced worsening of lower respiratory tract symptoms on dust storm days. Some studies noted that pollen could augment the influence of desert dust on the morbidity of asthma and rhinitis [86-88].

The above studies have shown an association between desert dust and an increased risk of exacerbation of asthma. However, dust events were not found to be significantly associated with the risk of hospitalization for asthma or the incidence of asthma attacks in Taipei and Fukuoka [81,89-91]. This discrepancy may be due to many factors, such as differences in materials attached to particulates during dust events in each country, differences in exposure concentration of transported dust particles, differences in the physical health of residents, and even differences in the preventative measures adopted. Overall, only a limited number of studies have focused on the association between asthma morbidity and dust events, and more studies need to be conducted covering broader areas in the future.

Dust is the major contributing factor triggering allergic rhinitis (or "hay fever") in the USA, Asia-Pacific, and Latin America [92]. Cakmak et al. [93] suggested that dust particles are the most important cause of allergic rhinitis, which might be induced by components of the dust or fungal spores present in the air. Sato T. [94] also reported that Asian sand dust may adversely affect allergic rhinitis symptoms regardless of dust storm levels. The prevalence of rhinitis in townships near the desert of Minqin, China was indicated by Yang et al. [95]. Chang et al. [96] reported the effect of sandstorms on allergic rhinitis in residents of Taipei, Taiwan, revealing that subjects exposed to sandstorms developed allergic rhinitis with a prevalence that was prominent in $19 \%$ of cases. Some of the rhinitis- and asthma-causing allergens, for example plant and grass pollens, fungal spores, molds, dust mites, anthropogenic emissions, and organic detritus, are also found in desert dusts [97-99]. 


\subsubsection{Desert Dust Associated with Pneumonia and Chronic Obstructive Pulmonary Disease}

There have been few global studies on the association between sand-dust storms and pneumonia. A high incidence of asthma, bronchitis and pneumonia was observed in Kano state, North West Nigeria during Saharan dust events reported by Uduma and Jimoh [100]. Korenyiboth et al. [101] highlighted that various kinds of organic pathogenic components of Saudi sand dust contributed to an opportunistic infection of pneumonitis. Ozer [102] suggested an augmentation of 2.79\% of acute respiratory infections per $10 \mu \mathrm{g} / \mathrm{m}^{3}$ increase in $\mathrm{PM}_{10}$ in Mauritania, North Africa. Meng et al. [103] found that dust events with a lag of six days were significantly associated with pneumonia in males, with an increase of $17 \%$ in Minqin, China. In the same study area, the prevalence of pneumonia and rhinitis in townships near the desert was higher than in townships far from the desert [95]. Moreover, Cheng et al. [104] indicated a statistically significant association between Asian dust storms and daily pneumonia admissions one day after the event in Taipei. Dust event days and post-dust event days 1 through 4 had significantly higher mean numbers of pneumonia admissions than those of non-dust days [105]. Gudavali et al. [106] revealed that exposure to particulate matter from Asian dust storms may be associated with desquamative interstitial pneumonia in susceptible patients in Korea.

Tam et al. [12] have shown that the numbers of daily emergency hospital admissions due to COPD one and two days after the dust storm days were significantly higher when compared with those on control days in Hong Kong. Positive but insignificant associations between Asian dust storms and hospital admissions for COPD have been reported in Taiwan [107], and emergency visits for COPD during high dust events increased by $20 \%$ compared to pre-dust periods [108]. Recently, Vodonos et al. [109] found a positive association between dust storms and rate of hospitalization for COPD exacerbation with an increase of $16 \%$ in Southern Israel, and the effect increased with age and was higher in women. In a laboratory study of young healthy adults, it was shown that women had an $11 \%-23 \%$ higher deposition of inhaled particles in the central airways when compared to men [110]. This gender difference was most notable for coarser particles $(>5 \mu \mathrm{m})$ and is assumed to be associated with women having narrower airways than men. The higher concentration of PM in the central airways induces a more intense irritation and inflammation, resulting in an acute exacerbation of COPD [111].

\subsubsection{Desert Dust and Other Respiratory Diseases}

Desert dust also deteriorates pulmonary function. Recent studies showed significantly reduced peak expiratory flow (PEF) values and more increased PEF variability during dust days than during the control days in Korea [112-115]. The same result was also reported in veterans exposed to dust storms, who exhibited a slightly better peak expiratory flow rate than veterans, who did not report exposure in the 1991 Gulf War [116]. Long-term exposure to desert dust particles will lead to nonindustrial pneumoconiosis or desert lung syndrome [117]. Currently, studies continue to examine dust and related health effects for troops deployed in desert regions of Iraq and Afghanistan to understand exposure as well as pathogens in the dust [118-124].

Chronic cough can result from hypersensitivity to environmental factors, such as chemicals, scents, cold air, and smoke [125], but there are only two reports of an association between Asian dust and chronic cough symptoms. The preliminary study from Higashi et al. [126] indicates that Asian dust triggers cough and allergic symptoms in adult patients suffering from chronic cough. A dose-response relationship between desert dust and daily cough occurrence and potential lag effects were observed in the panel study conducted by Higashi et al. [127], who also noted that the desert dust effect on cough was independent of other spherical particles or $\mathrm{PM}_{2.5}$. 


\subsubsection{Pathogeny of Desert Dust on Respiratory Diseases}

The quality and quantity of toxic materials (different amounts of lipopolysaccharides (LPS), $\beta$-glucan, $\mathrm{SiO}_{2}$, organic matters, and soluble metals) adsorbed onto desert dust particles varies between dust source regions and passage routes [128-130]. The health effect mechanisms of sand particle inhalation are incompletely understood. In vitro and in vivo methods are usually used to assess the role of different chemical components in the respiratory toxicity of sand particles [129].

Epithelial cells act as a physical barrier in the respiratory system, and also play important roles in the immune response against desert dust particles. These cells express different receptors such as Toll-like receptors (TLRs), C-type lectin receptors (CTRs), and protease-activated receptors (PARs) that can be triggered by different toxic materials from dust particles. Following receptor-mediated signaling, epithelial cells produce pro-inflammatory cytokines, such as (interleukin(IL)-1 $\beta$, IL-6, IL-8, IL-12, IL-17A interferon (IFN)- $\gamma$, TNF- $\alpha$ ) [131-133]. Then, elaboration of these cytokines initiates and exacerbates a Th2-type immune response in asthmatic patients [134,135]. After activation of Th2 cells, the Th2 cytokine pathway will be triggered; IL-4 and IL-13 are two major cytokines of Th2 cells, assisting in the production of IgE [136,137]. Among the other cytokines produced by Th2 cells, IL-5 has important roles in the terminal maturation of eosinophils $[138,139]$. On the other hand, pro-inflammatory cytokines are also involved in mucus production, airway remodeling, and release fibrosis factors such as TGF- $\beta 1$ [140-142]. In addition to Th2 cells, Th17 cells are a T cell effector subset that produces high levels of IL-17 and IL-22 cytokines and thus plays an important role in the pathogenesis of asthma and allergic airway disease [142-144].

Accompanying the release of pro-inflammatory cytokines, inflammatory mediators are also released by epithelial cells. This mechanism stimulates lymphocytes, dendritic cells, and granulocytes, including the recruitment of neutrophils, resulting in acute inflammation. Pathologically for pneumonia, desert dust particles enhance the neutrophil number dose-dependently, as well as the expression of cytokines (IL-1 $\beta$, IL-6, IL-8, IL-12, IFN- $\gamma$, TNF- $\alpha$ ) and chemokines (KC, MCP-1, MCP-3, MIP- $1 \alpha$ ) in bronchoalveolar lavage fluid [138,145-148]. These results suggest that the exacerbation of pneumonia by desert dust was due to the enhanced production of pro-inflammatory mediators via activation of TLR2 and NALP3 inflammasome pathways in alveolar macrophages [149]. Many study results suggest that the allergic inflammation aggravated by mineral dust may be due to mineral elements (mainly $\mathrm{SiO}_{2}$ ), and thus the biological effects of desert dust approximate those of silica $[138,150,151]$. Dust sampled from different sites over the world is dominated by silicon dioxide $\left(\mathrm{SiO}_{2}\right)$ and aluminum oxide $\left(\mathrm{Al}_{2} \mathrm{O}_{3}\right)$. Inhaling silicon dioxide in a certain amount can cause silicosis, rhinitis, bronchitis, and lung cancer, as the dust accumulates in the lungs and continuously irritates them, reducing respiratory function. Details of the effects on human health of exposure to aluminum oxide can be found in Krewski et al. [152].

The health effect mechanisms of sand particles on COPD are different from those on asthma $[153,154]$. In COPD, the innate immune response by $\mathrm{T}$ cytotoxic cells is perhaps more important than the acquired immune response for the development of persistent and progressive inflammation and remodeling of the lungs $[155,156]$.

The summarized pathological mechanisms of desert dust on human respiratory and immune systems are presented in Figure 5. It is widely accepted that desert dust has the capacity to (1) cause damage to the alveolar walls and bronchial epithelial cells through a direct physical effect; (2) influence oxidative stress and release of pro-inflammatory cytokines in respiratory epithelial cells; (3) damage DNA (the organic compounds and the insoluble particle-core might be the main contributors to DNA damage) [157]; and (4) cause a deterioration in pulmonary function. 


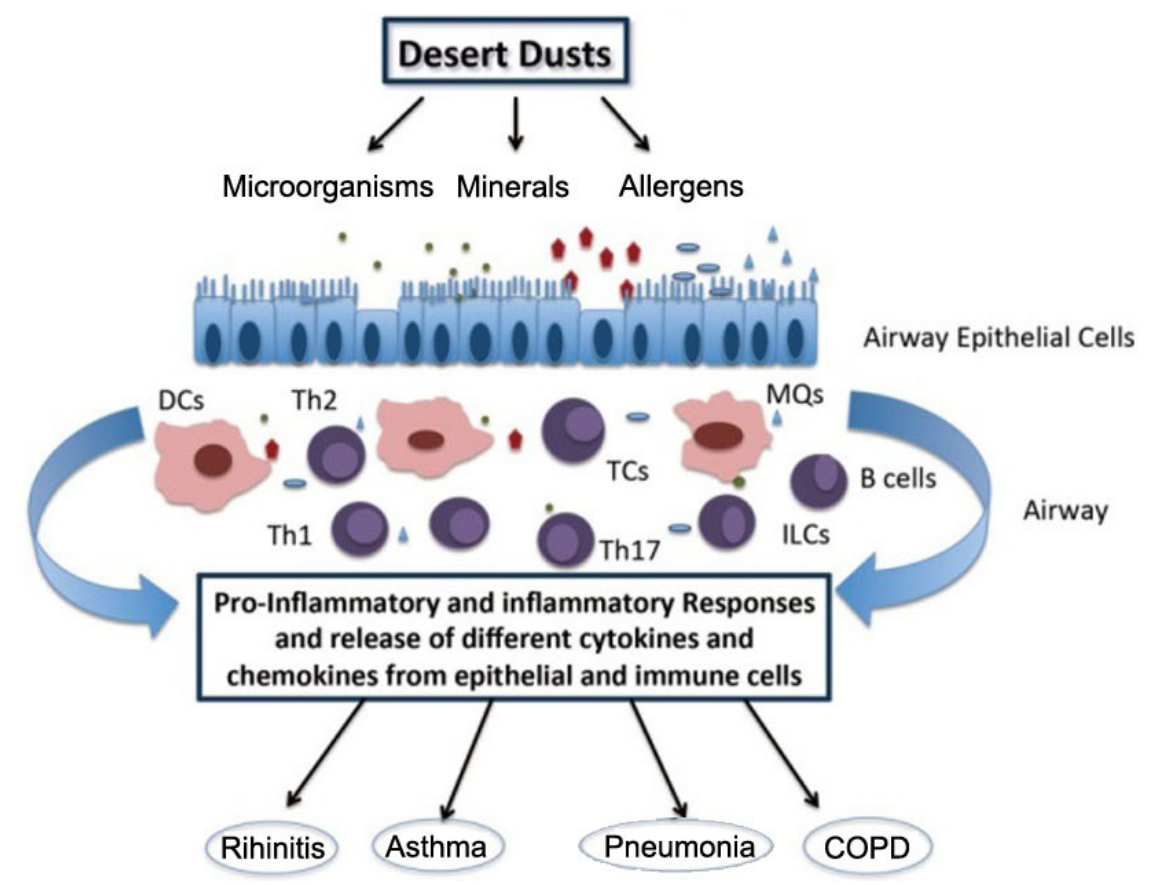

Figure 5. Schematic diagram of the pathological mechanisms of desert dust on the human respiratory system.

\subsection{Desert Dust and Cardiovascular Diseases}

Epidemiological studies have suggested that both cardiovascular mortality and morbidity increased during desert dust events. With an increase in $77.2 \mu \mathrm{g} / \mathrm{m}^{3} \mathrm{PM}_{10}$ per dust event, the emergency visits for cardiovascular diseases, ischemic heart diseases, and cerebrovascular diseases during the Asian dust events increased by 1.5 cases $(26 \%), 0.7$ cases $(35 \%)$, and 0.7 cases $(20 \%)$ per event, respectively, compared to the pre-dust periods in Taiwan [108]. Hospital admissions for ischemic heart disease were $16 \%$ to $21 \%$ higher on sandstorm days compared to other days [81]. Saharan dust also increased the effect of $\mathrm{PM}_{10}$ on cerebrovascular diseases with an increase of 5.04\% in Rome, Italy [158]. Dust storms caused a $\sim 1 \%$ increased cardiovascular morbidity in Iran [32]. A significant association between dust events with a lag of three days and hypertension in males was also found $(R R=1.30)$ in Minqin, China, and the association between the dust events and cardiovascular hospitalizations was stronger in spring and in winter [103]. The results of Zhang et al. [159] further suggest associations between $\mathrm{PM}_{2.5}$ and the increase in respiratory and cardiovascular diseases based on outpatient visits for males and females during the period when dust events frequently occur in Wuwei, Northwest China. A marginally significant increase in emergency hospital admissions for ischemic heart disease (IHD) was found, with RR $=1.04$ (95\% CI: $1.00-1.08)$ per $10 \mu \mathrm{g} / \mathrm{m}^{3}$ increase in the concentration of coarse particles of dust events in Hong Kong [160]. Middleton et al. [9] also observed an increased risk of hospitalization on dust storm days, particularly a $10.4 \%$ increase in cardiovascular causes in Nicosia, Cyprus.

The effects of dust storms on hospital admissions for cardiovascular disease (CVD) and congestive heart failure (CHF) were prominent $1 \mathrm{~d}$ after the event (3.65\% increase), but the association was not statistically significant in Taiwan [31,161]. There was also no significant increase in cardiovascular emergency department visits or in hospital admissions during the dust storm period in Sydney, Australia [78], but the occurrence of dust events 0 to $4 \mathrm{~d}$ before the day of hospital admission was significantly associated with the incidence of acute myocardial infarction [162].

The estimated relative risk of stroke admission was 1.022 (95\% CI: 0.995-1.049) on dust days in seven metropolitan areas in Korea [82]. In Taiwan, a statistically significant association between dust storm events and daily primary intracerebral hemorrhagic stroke admissions, and a positive 
but non-significant association between dust events and ischemic stroke admission three days after the event, were indicated by Yang et al. [163]. Kang et al. [164] found a significantly higher number of ischemic stroke admissions two days post-dust event but no difference in hemorrhagic stroke admissions. Kamouchi et al. [165] also indicated that Asian dust was not significantly associated with the overall incidence of ischemic stroke, but there was a relationship specific to the stroke subtypes such as atherothrombotic brain infarction in Japan.

Pathologically, once the inhaled dust particles that are deposited on the pulmonary alveoli, they can react chemically with the fluids and tissues, and then the toxic materials could penetrated into blood of circulatory system [166]. The concentrated dust storm particles cause sigmoid increases in heart rate and mean blood pressure and a sigmoid decrease of cardiac contractility $[167,168]$. At a cardiovascular level, there is vasoconstriction and increased blood pressure, along with a systemic inflammatory process caused by the release into the bloodstream of inflammatory mediators and prothrombotic factors [169].

\subsection{Desert Dust and Maternity and Reproduction}

Although desert particulate pollution has been shown to adversely affect pregnancy [170-173], the available evidence on the impact of dust episodes on pregnancy is scarce. Only one study evaluated the impact of Saharan dust episodes on pregnancy complications (preeclampsia and bacteriuria) and outcomes (birth weight and gestational age at delivery) based on a cohort of births in Barcelona, Spain [174]. The authors observed no statistically significant harmful effect of Saharan dust episodes on their included pregnancy complications and outcomes, and observed a small but statistically significant increase in gestational age at delivery in association with the number of episodic days during the third trimester and whole pregnancy ( 0.8 and 0.5 days, respectively). An animal-based experiment has also demonstrated that the male reproductive system of mice could be adversely affected by natural dust exposure as well as exposure to Asian dust and Arizona dust, which significantly decreased daily sperm production but caused no significant differences in serum testosterone concentration [175].

\subsection{Desert Dust and Other Infectious Diseases}

Conjunctivitis is an inflammation of the conjunctiva and other ocular surface as a result of reaction to an allergen. Yang et al. [176] observed an 11\% increase in the risk of clinic visits for conjunctivitis during the Asian dust events, although this increase was not statistically significant. Exposure to Asian dust may contribute to the pathophysiology of allergic rhinoconjunctivitis as an adjuvant to antigenic pollens and fungal elements [177].

Exposure to desert dust could also lead to skin symptoms, such as itching, eczema, pain, and reddish skin. Asian dust is widely suspected to be an important factor in the pathogenesis of atopic dermatitis [83]. The fungi, mites, and other potential allergens contained in Asian dust may be involved in the development of atopic dermatitis. Desert dust is particularly rich in calcium carbonate, but contains little iron [178-181]. A solution of calcium carbonate shows alkalinity, so desert dust may act like an exfoliant to open skin pores and remove the epithelium, thus provoking cutaneous inflammation in patients with atopic dermatitis [177]. The results of Otani et al. [182] provide preliminary evidence that Asian dust influences the allergic skin symptoms of healthy subjects, because the skin symptom scores were positively correlated with the suspended particulate matter level during dust events $(p<0.001)$. Skin symptoms during Asian dust events may reflect allergic reactions to Asian dust particle-bound metals such as nickel $[183,184]$, and thus the components and trajectories of Asian dust events should be considered when exploring the health effects of Asian dust events [185]. The toxicological effects of desert dust in human skin, investigated by Choi et al. [186] suggested that dust particles directly affect gene expression in human epidermal keratinocyte differentiation. In addition, Asian dust particles also increased gene transcription of the cytokines IL-6, IL-8, and GM-CSF, which have broad pro-inflammatory and immunomodulatory properties. 
Furthermore, some studies have identified an association between desert dust and uncomfortable eye symptoms such as itching, lacrimation, hyperemia, and bleary eyes. Zhou et al. [187] reported that sand and dust events increased symptoms in the eyes (dry eyes, eyes with foreign body sensation, and lacrimation) of schoolchildren in three cities of Southern Xinjiang, China. The occurrence of lacrimation was higher among the desert area participants compared to those residing in the urban area of Mongolia [188]. The daily prevalence of eye irritation was also significantly higher during the lag period after the dust event than during the control days in Korea [114]. In addition, during Asian dust periods when the daily levels of Japanese cedar pollen, Japanese cypress pollen, and PAHs were elevated, there were significantly more patients who experienced itchy eyes than during the non-Asian dust period [126].

Moreover, Doganay et al. [189] firstly revealed that atmospheric transport of Saharan dust has been able to trigger the trigeminovascular system in animals, but further studies are needed to explore the mechanisms and molecules that mediate the nociceptive effect and to guide new treatment strategies.

Dust storms may pick up and long-range transport the toxic trace elements and biologically active compounds (bacteria, fungi, pollen, spores and viruses) from natural or anthropogenic sources on a global scale [5,190-192]. All of the transported micro-organisms have potential implications for disease incidences, including meningococcal meningitis and coccidiomycosis.

Coccidioidomycosis is a common cause of community-acquired pneumonia in the southwest United States, Mexico, and South America, and is caused by the fungal pathogens Coccidioides immitis and C. posadasii [193]. These fungi occur in the soil of certain desert regions in the Western Hemisphere [119,194]. When airborne spores are inhaled by humans, infection develops in the lungs. The consequences of infection range from an inconsequential illness with resulting lifelong resistance to reinfection, through to severe and potentially life-threatening pneumonia or tissue destruction throughout the body [195].

Meningitis is an infection of the thin lining that surrounds the brain and spinal cord. The epidemic form of the disease is mainly caused by the bacterium Neisseria meningitidis. Human carriers transmit these bacteria through respiratory droplets or throat secretions. Meningitis has been associated with the dry climate conditions [196-200] and desert dust events [201-206]. Bacterial meningitis is an ongoing threat for the population of the African Meningitis Belt (Figure 6), a region characterized by the highest incidence rates worldwide. In order to intuitively demonstrate the possible relationship between Saharan dust and African Meningitis Belt, we further drawn the spatial aerosol optical depth distribution of dust extinction from the second Modern-Era Retrospective analysis for Research and Applications (MERRA-2) satellite data for January 1980 to December 2015 in Figure 6. It is clearly that the Meningitis Belt is mainly located at the southern margin of African dust belt. The determinants of the disease dynamics are still poorly understood; nevertheless, it is often advocated that climate and mineral dust have a large impact. The quantitative dust/meningitis studies have been quite well reported in recent years comparatively to climate-related studies. A questionable but interesting assumption is that Saharan dust may provide the bacteria $N$. meningitides with the iron required for growth [204,207]. Recently, Agier et al. [203] found spatially consistent time-lags between seasonal components and dust events at a fine spatial scale (sanitary district); this finding, together with the assumption of dust damaging the pharyngeal mucosa and easing bacterial invasion, reinforces the notion that dust impacts meningitis' seasonality. 


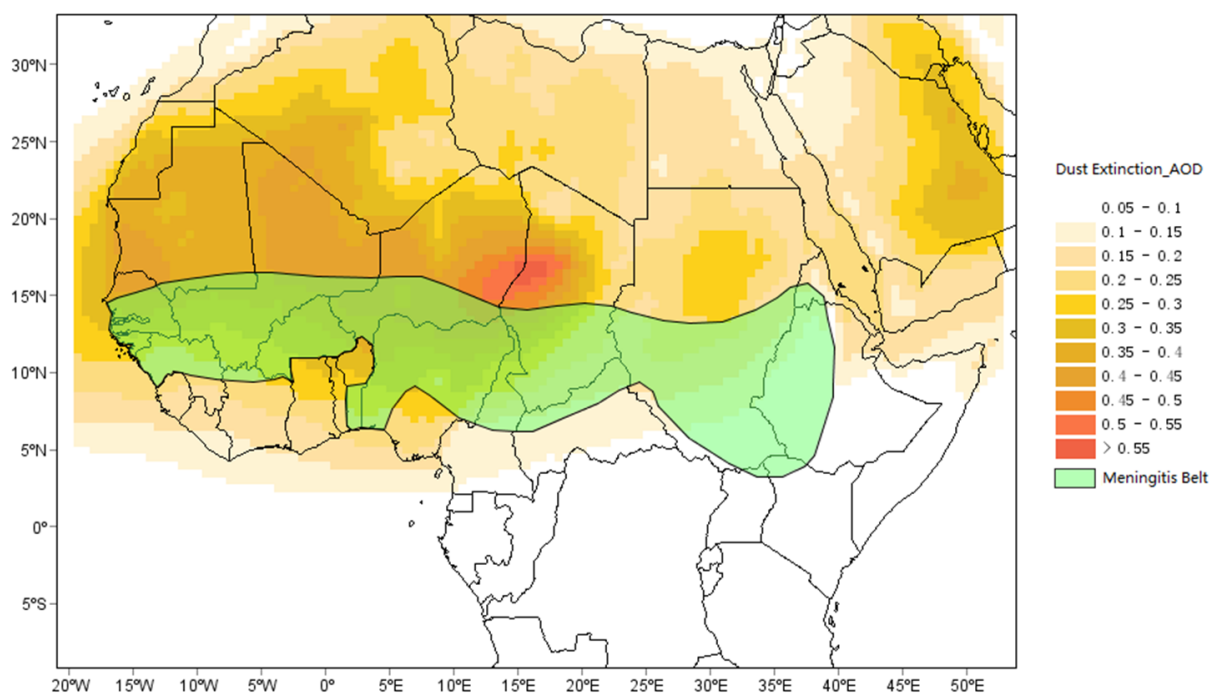

Figure 6. Geographical distribution of meningitis belt [208] and reanalyzed satellite observed aerosol optical depth of dust extinction (MERRA-2, Range from January 1980 to December 2015, accessed on DATE) over North Africa.

\section{Conclusions and Perspective}

Our knowledge gained from both an epidemiological and mechanistic standpoint regarding the association between desert dust and human health disorders has expanded greatly in the past decades. Among the human health effects of dust storms are respiratory disorders (including asthma, tracheitis, pneumonia, chronic obstructive pulmonary disease, allergic rhinitis, and silicosis), cardiovascular disorders (including stroke, arrhythmia, ischemic heart disease, and cerebrovascular disease), dermatological disorders, and, more rarely, conjunctivitis, exacerbated cough, reproductive disorders, headache, and infectious diseases such as bacterial meningitis and the diseases associated with transported micro-organisms in desert dust (Coccidioidomycosis).

This review also reveals an imbalance between the areas most exposed to dust and the areas most studied in terms of health effects. Asian and Saharan dust are by far the most frequently studied in the epidemiological literature, which mainly focuses on the health effects in neighboring countries/areas around the desert sources, while very few studies have investigated the health effects of intercontinental transported dust. Other dust sources (Australian and North American) are also explored but, despite the presence of important dust sources over southern South America, no studies of dust's impact on health in South America have been published. Moreover, the pathological and aerobiological studies are also focused on Asian dust and only a very few studies refer to other dust sources.

Overall, for respiratory and circulatory mortality, both positive and negative associations have been reported for $\mathrm{PM}_{10}$, but only a positive relationship was reported between $\mathrm{PM}_{2.5-10}$ and mortality, and a positive relationship was also reported between $\mathrm{PM}_{2.5}$ and human mortality. The plausible explanation for the inconsistent relationships between mortality effects and coarse fraction PM is the diversity in the geographical distribution of study areas, dust source areas, and dust trajectories. Moreover, the toxicological properties of the desert dust particles might be modified by mixing with anthropogenic emissions from industrial regions on different transport paths. Future studies should focus on the chemical characterization of the coarse particle mode on human health effects during the dust storm episodes. Future pathological studies should continue to focus on those desert dust mechanisms causing the most harmful effects in terms of respiratory and cardiovascular diseases. More attention should also be paid to the association between desert dust and other diseases, such as those affecting the reproductive system and nervous system. Finally, further research should focus on 
dust size fractions and the specific chemical composition harmful to human health, so that findings may be directly linked to policy decisions.

The increasing availability of information about dust storms from ground-based observations, numerical models, and satellite remote sensing means that there is now the potential for health effects to be explored in greater detail through collaborations between medical staff and environmental scientists.

Supplementary Materials: The following are available online at www.mdpi.com/2073-4433/7/12/158/s1. Table S1: Summary of total 103 epidemiological studies included with searching conditions for health effects of desert dust, Table S2: Summary of total 73 pathological studies included with searching conditions for health effects of desert dust, Table S3: Summary of total 54 general identified airborne microbiology studies related to dust storms over the world.

Acknowledgments: This work was financially supported by the National Natural Science Foundation of China (NSFC) (No. 41571063 and 21407148) and the CAS/SAFEA International Partnership Program for Creative Research Teams (No. KZZD-EW-TZ-07). The authors would like to thank Qinqian Zhou and Tianli Xu for their recommendations to improve this manuscript.

Author Contributions: Teng Bo and Mo Dan Carried out literature searching, collection and data analysis; Danile Q. Tong gave revision suggestions for this manuscript; Xuelei Zhang, Lijing Zhao and Guangjian Wu defined the review scheme and finished this manuscript.

Conflicts of Interest: The authors declare no conflict of interest.

\section{References}

1. Shao, Y.; Wyrwoll, K.H.; Chappell, A.; Huang, J.; Lin, Z.; McTainsh, G.H.; Mikami, M.; Tanaka, T.Y.; Wang, X.; Yoon, S. Dust cycle: An emerging core theme in Earth system science. Aeolian Res. 2011, 2, 181-204. [CrossRef]

2. Mahowald, N.M.; Kloster, S.; Engelstaedter, S.; Moore, J.K.; Mukhopadhyay, S.; McConnell, J.R.; Albani, S.; Doney, S.C.; Bhattacharya, A.; Curran, M.A.J.; et al. Observed 20th century desert dust variability: Impact on climate and biogeochemistry. Atmos. Chem. Phys. 2010, 10, 10875-10893. [CrossRef]

3. De Longueville, F.; Hountondji, Y.C.; Henry, S.; Ozer, P. What do we know about effects of desert dust on air quality and human health in West Africa compared to other regions? Sci. Total Environ. 2010, 409, 1-8. [CrossRef] [PubMed]

4. Giannadaki, D.; Pozzer, A.; Lelieveld, J. Modeled global effects of airborne desert dust on air quality and premature mortality. Atmos. Chem. Phys. 2014, 14, 957-968. [CrossRef]

5. Gonzalez-Martin, C.; Teigell-Perez, N.; Valladares, B.; Griffin, D.W. The Global dispersion of pathogenic microorganisms by dust storms and its relevance to agriculture. Adv. Argonomy 2014, 127, 1-41.

6. Kwon, H.J.; Cho, S.H.; Chun, Y.; Lagarde, F.; Pershagen, G. Effects of the Asian dust events on daily mortality in Seoul, Korea. Environ. Res. 2002, 90, 1-5. [CrossRef] [PubMed]

7. Chen, Y.S.; Sheen, P.C.; Chen, E.R.; Liu, Y.K.; Wu, T.N.; Yang, C.Y. Effects of Asian dust storm events on daily mortality in Taipei, Taiwan. Environ. Res. 2004, 95, 151-155. [CrossRef] [PubMed]

8. Bennett, C.M.; McKendry, I.G.; Kelly, S.; Denike, K.; Koch, T. Impact of the 1998 Gobi dust event on hospital admissions in the Lower Fraser Valley, British Columbia. Sci. Total Environ. 2006, 366, 918-925. [CrossRef] [PubMed]

9. Middleton, N.; Yiallouros, P.; Kleanthous, S.; Kolokotroni, O.; Schwartz, J.; Dockery, D.W.; Demokritou, P.; Koutrakis, P. A 10-year time-series analysis of respiratory and cardiovascular morbidity in Nicosia, Cyprus: The effect of short-term changes in air pollution and dust storms. Environ. Health 2008, 7, 1-16. [CrossRef] [PubMed]

10. Pérez, L.L.; Tobias, A.; Querol, X.; Künzli, N.; Pey, J.; Alastuey, A.; Viana, M.; Valero, N.; González-Cabré, M.; Sunyer, J. Coarse particles from Saharan dust and daily mortality. Epidemiology 2008, 19, 800-807. [CrossRef] [PubMed]

11. Mallone, S.; Stafoggia, M.; Faustini, A.; Gobbi, G.P.; Marconi, A.; Forastiere, F. Saharan dust and associations between particulate matter and daily mortality in Rome, Italy. Environ. Health Perspect. 2011, 119, 1409. [CrossRef] [PubMed]

12. Tam, W.W.S.; Wong, T.W.; Wong, A.H.S.; Hui, D.S. Effect of dust storm events on daily emergency admissions for respiratory diseases. Respirology 2012, 17, 143-148. [CrossRef] [PubMed] 
13. Neophytou, A.M.; Yiallouros, P.; Coull, B.A.; Kleanthous, S.; Pavlou, P.; Pashiardis, S.; Dockery, D.W.; Koutrakis, P.; Laden, F. Particulate matter concentrations during desert dust outbreaks and daily mortality in Nicosia, Cyprus. J. Expo. Sci. Environ. Epidemiol. 2013, 23, 275-280. [CrossRef] [PubMed]

14. Hashizume, M.; Ueda, K.; Nishiwaki, Y.; Michikawa, T.; Onozuka, D. Health effects of Asian dust events: A review of the literature. Nihon Eiseigaku Zasshi 2010, 65, 413-421. [CrossRef] [PubMed]

15. Kwon, H.J. Toxicity and health effects of Asian dust: A literature review. J. Korean Med. Assoc. 2012, 55, 234-242. [CrossRef]

16. Karanasiou, A.; Moreno, N.; Moreno, T.; Viana, M.; De Leeuw, F.; Querol, X. Health effects from Sahara dust episodes in Europe: Literature review and research gaps. Environ. Int. 2012, 47, 107-114. [CrossRef] [PubMed]

17. De Longueville, F.; Ozer, P.; Doumbia, S.; Henry, S. Desert dust impacts on human health: An alarming worldwide reality and a need for studies in West Africa. Int. J. Biometeorol. 2013, 57, 1-19. [CrossRef] [PubMed]

18. Goudie, A.S. Desert dust and human health disorders. Environ. Int. 2014, 63, 101-113. [CrossRef] [PubMed]

19. Lee, H.; Honda, Y.; Lim, Y.H.; Guo, Y.L.; Hashizume, M.; Kim, H. Effect of Asian dust storms on mortality in three Asian cities. Atmos. Environ. 2014, 89, 309-317. [CrossRef]

20. Al-Taiar, A.; Thalib, L. Short-term effect of dust storms on the risk of mortality due to respiratory, cardiovascular and all-causes in Kuwait. Int. J. Biometeorol. 2014, 58, 69-77. [CrossRef] [PubMed]

21. Samoli, E.; Kougea, E.; Kassomenos, P.; Analitis, A.; Katsouyanni, K. Does the presence of desert dust modify the effect of $\mathrm{PM}_{10}$ on mortality in Athens, Greece? Sci. Total Environ. 2011, 409, 2049-2054. [CrossRef] [PubMed]

22. Sajani, S.Z.; Miglio, R.; Bonasoni, P.; Cristofanelli, P.; Marinoni, A.; Sartini, C.; Goldoni, C.A.; Girolamo, G.D.; Lauriola, P. Saharan dust and daily mortality in Emilia-Romagna (Italy). Occup. Environ. Med. 2010. [CrossRef]

23. Hwang, S.S.; Cho, S.H.; Kwon, H.J. Effects of the severe Asian dust events on daily mortality during the spring of 2002, in Seoul, Korea. J. Prev. Med.Public Health 2005, 38, 197-202. [PubMed]

24. Lee, H.; Kim, H.; Honda, Y.; Lim, Y.H.; Yi, S. Effect of Asian dust storms on daily mortality in seven metropolitan cities of Korea. Atmos. Environ. 2013, 79, 510-517. [CrossRef]

25. Lee, J.T.; Son, J.Y.; Cho, Y.S. A comparison of mortality related to urban air particles between periods with Asian dust days and without Asian dust days in Seoul, Korea, 2000-2004. Environ. Res. 2007, 105, 409-413. [CrossRef] [PubMed]

26. Chan, C.C.; Ng, H.C. A case-crossover analysis of Asian dust storms and mortality in the downwind areas using 14-year data in Taipei. Sci. Total Environ. 2011, 410, 47-52. [CrossRef] [PubMed]

27. Díaz, J.; Tobías, A.; Linares, C. Saharan dust and association between particulate matter and case-specific mortality: A case-crossover analysis in Madrid (Spain). Environ. Health 2012, 11, 11. [CrossRef] [PubMed]

28. Johnston, F.; Hanigan, I.; Henderson, S.; Morgan, G.; Bowman, D. Extreme air pollution events from bushfires and dust storms and their association with mortality in Sydney, Australia 1994-2007. Environ. Res. 2011, 111, 811-816. [CrossRef] [PubMed]

29. Jiménez, E.; Linares, C.; Martínez, D.; Díaz, J. Role of Saharan dust in the relationship between particulate matter and short-term daily mortality among the elderly in Madrid (Spain). Sci. Total Environ. 2010, 408, 5729-5736. [CrossRef] [PubMed]

30. Kim, H.S.; Kim, D.S.; Kim, H.; Yi, S.M. Relationship between mortality and fine particles during Asian dust, smog-Asian dust, and smog days in Korea. Int. J. Environ. Health Res. 2012, 22, 518-530. [CrossRef] [PubMed]

31. Tobías, A.; Pérez, L.; Díaz, J.; Linares, C.; Pey, J.; Alastruey, A.; Querol, X. Short-term effects of particulate matter on total mortality during Saharan dust outbreaks: A case-crossover analysis in Madrid (Spain). Sci. Total Environ. 2011, 412, 386-389. [CrossRef] [PubMed]

32. Delangizan, S.; Jafari Motlagh, Z. Dust phenomenon effects on cardiovascular and respiratory hospitalizations and mortality-A case study in Kermanshah, during March-September 2010-2011. Iran. J. Health Environ. 2013, 6, 65-76.

33. Kashima, S.; Yorifuji, T.; Tsuda, T.; Eboshida, A. Asian dust and daily all-cause or cause-specific mortality in western Japan. Occup. Environ. Med. 2012, 69, 908-915. [CrossRef] [PubMed] 
34. Maté, T.; Guaita, R.; Pichiule, M.; Linares, C.; Díaz, J. Short-term effect of fine particulate matter $\left(\mathrm{PM}_{2.5}\right)$ on daily mortality due to diseases of the circulatory system in Madrid (Spain). Sci. Total Environ. 2010, 408, 5750-5757. [CrossRef] [PubMed]

35. Ginoux, P.; Chin, M.; Tegen, I.; Prospero, J.M.; Holben, B.; Dubovik, O.; Lin, S.J. Sources and distributions of dust aerosols simulated with the GOCART model. J. Geophys. Res.: Atmos. (1984-2012) 2001, 106, 20255-20273. [CrossRef]

36. Prospero, J.M.; Ginoux, P.; Torres, O.; Nicholson, S.E.; Gill, T.E. Environmental characterization of global sources of atmospheric soil dust identified with the Nimbus 7 Total Ozone Mapping Spectrometer (TOMS) absorbing aerosol product. Rev. Geophys. 2002, 40. [CrossRef]

37. Tanaka, T.Y.; Chiba, M. A numerical study of the contributions of dust source regions to the global dust budget. Glob. Planet. Chang. 2006, 52, 88-104. [CrossRef]

38. Huneeus, N.; Schulz, M.; Balkanski, Y.; Griesfeller, J.; Kinne, S.; Prospero, J.; Bauer, S.; Boucher, O.; Chin, M.; Dentener, F.; et al. Global dust model intercomparison in AeroCom phase I. Atmos. Chem. Phys. 2011, 11, 7781-7816. [CrossRef]

39. Varga, G. Spatio-temporal distribution of dust storms-A global coverage using NASA TOMS aerosol measurements. Hung Geogr. Bull. 2012, 61, 275-298.

40. Ginoux, P.; Prospero, J.M.; Gill, T.E.; Hsu, N.C.; Zhao, M. Global-scale attribution of anthropogenic and natural dust sources and their emission rates based on MODIS deep blue aerosol products. Rev. Geophys. 2012, 50, RG3005. [CrossRef]

41. Tegen, K.; Schepanski, K. The global distribution of mineral dust. In IOP Conference Series: Earth and Environmental Science; IOP: Barcelona, Spain, 2009; Volume 7. [CrossRef]

42. Zhang, X.; Tong, D.Q.; Wu, G.; Wang, X.; Xiu, A.; Han, Y.; Xu, T.; Zhang, S.; Zhao, H. Identification of dust sources and hotspots in East Asia during 2000-2015: Implications for numerical modeling and forecasting. Atmos. Chem. Phys. Discuss. 2016. [CrossRef]

43. Uno, I.; Eguchi, K.; Yumimoto, K.; Takemura, T.; Shimizu, A.; Uematsu, M.; Liu, Z.; Wang, Z.; Hara, Y.; Sugimoto, N. Asian dust transported one full circuit around the globe. Nat. Geosci. 2009, 2, 557-560. [CrossRef]

44. Escudero, M.; Stein, A.F.; Draxler, R.R.; Querol, X.; Alastuey, A.; Castillo, S.; Avila, A. Source apportionment for African dust outbreaks over the Western Mediterranean using the HYSPLIT model. Atmos. Res. 2011, 99 , 518-527. [CrossRef]

45. Israelevich, P.; Ganor, E.; Alpert, P.; Kishcha, P.; Stupp, A. Predominant transport paths of Saharan dust over the Mediterranean Sea to Europe. J. Geophys. Res.: Atmos. (1984-2012) 2012, 117, D02205. [CrossRef]

46. Varga, G.; Kovács, J.; Újvári, G. Analysis of Saharan dust intrusions into the Carpathian Basin (Central Europe) over the period of 1979-2011. Glob. Planet. Chang. 2013, 100, 333-342. [CrossRef]

47. Tanaka, T.Y.; Kurosaki, Y.; Chiba, M.; Matsumura, T.; Nagai, T.; Yamazaki, A.; Uchiyama, A.; Tsunematsu, N.; Kai, K. Possible transcontinental dust transport from North Africa and the Middle East to East Asia. Atmos. Environ. 2005, 39, 3901-3909. [CrossRef]

48. Ben-Ami, Y.; Koren, I.; Rudich, Y.; Artaxo, P.; Martin, S.T.; Andreae, M.O. Transport of North African dust from the Bodélé depression to the Amazon Basin: A case study. Atmos. Chem. Phys. 2010, 10, 7533-7544. [CrossRef]

49. Barkan, J.; Alpert, P. Synoptic analysis of a rare event of Saharan dust reaching the Arctic region. Weather 2010, 65, 208-211. [CrossRef]

50. Sunnu, A.; Resch, F.; Afeti, G. Back-trajectory model of the Saharan dust flux and particle mass distribution in West Africa. Aeolian Res. 2013, 9, 125-132. [CrossRef]

51. McTainsh, G.H.; Nickling, W.G.; Lynch, A.W. Dust deposition and particle size in Mali, West Africa. Catena 1997, 29, 307-322. [CrossRef]

52. Breuning-Madsen, H.; Awadzi, T.W. Harmattan dust deposition and particle size in Ghana. Catena 2005, 63, 23-38. [CrossRef]

53. Anuforom, A.C. Spatial distribution and temporal variability of Harmattan dust haze in sub-Sahel West Africa. Atmos. Environ. 2007, 41, 9079-9090. [CrossRef]

54. Resch, F.; Sunnu, A.; Afeti, G. Saharan dust flux and deposition rate near the Gulf of Guinea. Tellus B 2008, 60, 98-105. [CrossRef] 
55. Ridley, D.A.; Heald, C.L.; Prospero, J.M. What controls the recent changes in African mineral dust aerosol across the Atlantic? Atmos. Chem. Phys. Discuss. 2014, 14, 3583-3627. [CrossRef]

56. Prospero, J.M.; Mayol-Bracero, O.L. Uderstanding the transport and imapct of Afican dust on the Caribbean Basin. Bull. Am. Meteorol. Soc. 2013, 94, 1329-1337. [CrossRef]

57. Kallos, G.; Astitha, M.; Katsafados, P.; Spyrou, C. Long-range transport of anthropogenically and naturally produced particulate matter in the Mediterranean and North Atlantic: Current state of knowledge. J. Appl. Meteorol. Climatol. 2007, 46, 1230-1251. [CrossRef]

58. Pey, J.; Querol, X.; Alastuey, A.; Forastiere, F.; Stafoggia, M. African dust outbreaks over the Mediterranean Basin during 2001-2011: $\mathrm{PM}_{10}$ concentrations, phenomenology and trends, and its relation with synoptic and mesoscale meteorology. Atmos. Chem. Phys. 2013, 13, 1395-1410. [CrossRef]

59. International Classification of Diseases, Version 9. Available online: http://www.cdc.gov $/ \mathrm{nchs} / \mathrm{icd} / \mathrm{icd} 9 \mathrm{~cm} . \mathrm{htm}$ (accessed on 25 November 2016).

60. International Classification of Diseases, Version 10. Available online: http://apps.who.int/classifications / icd10/browse/2016/en (accessed on 25 November 2016).

61. Dominici, F.; McDermott, A.; Zeger, S.L.; Samet, J.M. On the use of generalized additive models in time-series studies of air pollution and health. Am. J. Epidemiol. 2002, 156, 193-203. [CrossRef] [PubMed]

62. Richardson, D.B.; Loomis, D. The impact of exposure categorisation for grouped analyses of cohort data. Occup. Environ. Med. 2004, 61, 930-935. [CrossRef] [PubMed]

63. Griffin, D.W. Atmospheric movement of microorganisms in clouds of desert dust and implications for human health. Clin. Microbiol. Rev. 2007, 20, 459-477. [CrossRef] [PubMed]

64. Ostro, B.; Tobias, A.; Querol, X.; Alastuey, A.; Amato, F.; Pey, J.; Pérez, N.; Sunyer, J. The effects of particulate matter sources on daily mortality: A case crossover study of Barcelona Spain. Environ. Health Perspect. 2011, 119, 1781. [CrossRef] [PubMed]

65. Lopez-Villarrubia, E.; Iñiguez, C.; Ballester, F.; Peral, N.; García, D. Association of fine and coarse particles with mortality in Canary Island cities affected by Saharan dust intrusion. Epidemiology 2009, 20, S199-S200. [CrossRef]

66. Hashizume, M.; Nishiwaki, Y.; Michikawa, T.; Ueda, K.; Onozuka, D.; Yokota, K.; Mine, M.; Mori, A.; Shimizu, A.; Sugimoto, N.; et al. Effects of Asian dust events on daily mortality in Nagasaki, Japan. Epidemiology 2011, 22, S130. [CrossRef]

67. Pérez, L.; Tobías, A.; Querol, X.; Pey, J.; Alastuey, A.; Díaz, J.; Sunyer, J. Saharan dust, particulate matter and cause-specific mortality: A case-crossover study in Barcelona (Spain). Environ. Int. 2012, 48, 150-155. [CrossRef] [PubMed]

68. Chen, Y.S.; Yang, C.Y. Effects of Asian dust storm events on daily hospital admissions for cardiovascular disease in Taipei, Taiwan. J. Toxicol. Environ. Health Part A 2005, 68, 1457-1464. [CrossRef] [PubMed]

69. Rodríguez, S.; Alastuey, A.; Alonso-Pérez, S.; Querol, X.; Cuevas, E.; Abreu-Afonso, J.; Viana, M.; Pérez, N.; Pandolfi, M.; de la Rosa, J. Transport of desert dust mixed with North African industrial pollutants in the subtropical Saharan Air Layer. Atmos. Chem. Phys. 2011, 11, 6663-6685. [CrossRef]

70. Hsieh, N.H.; Liao, C.M. Assessing exposure risk for dust storm events-associated lung function decrement in asthmatics and implications for control. Atmos. Environ. 2013, 68, 6e264. [CrossRef]

71. Roy, C.J.; Milton, D.K. Airborne transmission of communicable infection-the elusive pathway. N. Engl. J. Med. 2004, 350, 1710-1712. [CrossRef] [PubMed]

72. Prospero, J.M.; Blades, E.; Naidu, R.; Mathison, G.; Thani, H.; Lavoie, M.C. Relationship between African dust carried in the Atlantic trade winds and surges in pediatric asthma attendances in the Caribbean. Int. J. Biometeorol. 2008, 52, 823-832. [CrossRef] [PubMed]

73. Gyan, K.; Henry, W.; Lacaille, S.; Laloo, A.; Lamsee-Ebanks, C.; McKay, S.; Antoine, R.M.; Monteil, M.A. African dust clouds are associated with increased paediatric asthma accident and emergency admissions on the Caribbean island of Trinidad. Int. J. Biometeorol. 2005, 49, 371-376. [CrossRef] [PubMed]

74. Cadelis, G.; Tourres, R.; Molinie, J. Short-term effects of the particulate pollutants contained in Saharan dust on the visits of children to the emergency department due to asthmatic conditions in Guadeloupe (French Archipelago of the Caribbean). PLoS ONE 2014, 9, e91136. [CrossRef] [PubMed]

75. Meo, S.A.; Al-Kheraiji, M.F.A.; AlFaraj, Z.F.; abdulaziz Alwehaibi, N.; Aldereihim, A.A. Respiratory and general health complaints in subjects exposed to sandstorm at Riyadh, Saudi Arabia. Pak. J. Med. Sci. 2013, 29, 642. [CrossRef] [PubMed] 
76. Thalib, L.; Al-Taiar, A. Dust storms and the risk of asthma admissions to hospitals in Kuwait. Sci. Total Environ. 2012, 433, 347-351. [CrossRef] [PubMed]

77. Rutherford, S.; Clark, E.; McTainsh, G.; Simpson, R.; Mitchell, C. Characteristics of rural dust events shown to impact on asthma severity in Brisbane, Australia. Int. J. Biometeorol. 1999, 42, 217-225. [CrossRef] [PubMed]

78. Merrifield, A.; Schindeler, S.; Jalaludin, B.; Smith, W. Health effects of the September 2009 dust storm in Sydney, Australia: Did emergency department visits and hospital admissions increase? Environ. Health 2013, 12, 32. [CrossRef] [PubMed]

79. Samoli, E.; Nastos, P.T.; Paliatsos, A.G.; Katsouyanni, K.; Priftis, K.N. Acute effects of air pollution on pediatric asthma exacerbation: Evidence of association and effect modification. Environ. Res. 2011, 111, 418-424. [CrossRef] [PubMed]

80. Grineski, S.E.; Staniswalis, J.G.; Bulathsinhala, P.; Peng, Y.; Gill, T.E. Hospital admissions for asthma and acute bronchitis in El Paso, Texas: Do age, sex, and insurance status modify the effects of dust and low wind events? Environ. Res. 2011, 111, 1148-1155. [CrossRef] [PubMed]

81. Bell, M.L.; Levy, J.K.; Lin, Z. The effect of sandstorms and air pollution on cause-specific hospital admissions in Taipei, Taiwan. Occup. Environ. Med. 2008, 65, 104-111. [CrossRef] [PubMed]

82. Lee, E.C.; Leem, J.; Hong, Y.C.; Kim, H.; Kim, H.C. Effects of Asian dust storm events on daily admissions for asthma and stroke in seven metropolitans of Korea. Epidemiology 2008, 19, S145.

83. Lee, J.W.; Lee, K.K. Effects of Asian dust events on daily asthma patients in Seoul, Korea. Meteorol. Appl. 2014, 21, 202-209. [CrossRef]

84. Kanatani, K.T.; Ito, I.; Al-Delaimy, W.K.; Adachi, Y.; Mathews, W.C.; Ramsdell, J.W. Desert dust exposure is associated with increased risk of asthma hospitalization in children. Am. J. Respir. Crit. Care Med. 2010, 182, 1475-1481. [CrossRef] [PubMed]

85. Watanabe, M. Influence of Asian dust storms on asthma in western Japan. Genes Environ. 2014, 36, 137-144. [CrossRef]

86. AI-Dowaisan, A.; Fakim, N.; Khan, M.R.; Arifhodzic, N.; Panicker, R.; Hanoon, A.; Khan, I. Salsola pollen as a predominant cause of respiratory allergies in Kuwait. Ann. Allergy Asthma Immunol. 2004, 92, $262-267$. [CrossRef]

87. Ichinose, T.; Hiyoshi, K.; Yoshida, S.; Takano, H.; Inoue, K.; Nishikawa, M.; Mori, I.; Kawazato, H.; Yasuda, A.; Shibamoto, T. Asian sand dust aggravates allergic rhinitis in guinea pigs induced by Japanese cedar pollen. Inhal. Toxicol. 2009, 21, 985-993. [CrossRef] [PubMed]

88. Watanabe, M.; Igishi, T.; Burioka, N.; Yamaski, A.; Kurai, J.; Takeuchi, H.; Sako, T.; Yoshida, A.; Yoneda, K.; Fukuoka, Y.; et al. Pollen augments the influence of desert dust on symptoms of adult asthma patients. Allergol. Int. 2011, 60, 517. [CrossRef] [PubMed]

89. Ueda, K.; Nitta, H.; Odajima, H. The effects of weather, air pollutants, and Asian dust on hospitalization for asthma in Fukuoka. Environ. Health Prev. Med. 2010, 15, 350-357. [CrossRef] [PubMed]

90. Yang, C.Y.; Tsai, S.S.; Chang, C.C.; Ho, S.C. Effects of Asian dust storm events on daily admissions for asthma in Taipei, Taiwan. Inhal. Toxicol. 2005, 17, 817-821. [CrossRef] [PubMed]

91. Min, P.K.; Kim, C.W.; Yun, Y.J.; Chang, J.H.; Chu, J.K.; Lee, K.E.; Han, J.Y.; Park, J.W.; Hong, C.S. Effect of yellow sand on respiratory symptoms and diurnal variation of peak expiratory flow in patients with bronchial asthma. J. Asthma, Allergy Clin. Immunol. 2001, 21, 1179-1186.

92. Meltzer, E.O.; Blaiss, M.S.; Naclerio, R.M.; Stoloff, S.W.; Derebery, M.J.; Nelson, H.S.; Boyle, J.M.; Wingertzahn, M.A. Burden of allergic rhinitis: Allergies in America, Latin America, and Asia-Pacific adult surveys. Allergy Asthma Proc. 2012, 33, S113-S141. [CrossRef] [PubMed]

93. Cakmak, S.; Dales, R.E.; Burnett, R.T.; Judek, S.; Coates, F.; Brook, J.R. Effect of airborne allergens on emergency visits by children for conjunctivitis and rhinitis. Lancet 2002, 16, 947-948. [CrossRef]

94. Sato, T. The study on the change of symptoms in allergic rhinitis during Asian sand dust phenomenon. Practica Oto-Rhino-Laryngologica 2009, 102, 831-839. [CrossRef]

95. Yang, Z.H.; Meng, Z.Q.; Pan, J.J.; Yan, X.Z. Epidemiological survey on the diseases of the respiratory and circulatory system among the people in a region where dust events occurred frequently. J. Environ. Occup. Med. 2008, 1, 004.

96. Chang, C.C.; Lee, I.M.; Tsai, S.S.; Yang, C.Y. Correlation of Asian dust storm events with daily clinic visits for allergic rhinitis in Taipei, Taiwan. J. Toxicol. Environ. Health Part A 2006, 69, 229-235. [CrossRef] [PubMed] 
97. Bjorksten, B.; Dumitrascu, D.; Foucard, T.; Khetsuriani, N.; Khaitov, R.; Leja, M.; Lis, G.; Pekkanen, J.; Priftanji, A.; Riikjarv, M.A. Prevalence of childhood asthma, rhinitis and eczema in Scandinavia and Eastern Europe. Eur. Respir. J. 1998, 12, 432-437. [CrossRef] [PubMed]

98. Ezeamuzie, C.I.; Thomson, M.S.; Al-Ali, S.; Dowaisan, A.; Khan, M.; Hijazi, Z. Asthma in the desert: Spectrum of the sensitizing aeroallergens. Allergy 2000, 55, 157-162. [CrossRef] [PubMed]

99. Shamssain, M.H.; Shamsian, N. Prevalence and severity of asthma, rhinitis, and atopic eczema in 13- to 14-year-old schoolchildren from the northeast of England. Ann. Allergy Asthma Immunol. 2001, 86, 428-432. [CrossRef]

100. Uduma, A.U.; Jimoh, W.L.O. High incidence of Asthma, Bronchitis, Pneumonia and Sinusitis in Kano State, North West Nigeria during Saharan dust events. Am. J. Environ. Energy Power Res. 2013, 1, 174-185.

101. Korenyi-Both, A.L.; Molnar, A.C.; Fidelus-Gort, R. Al Eskan disease: Desert storm pneumonitis. Mil. Med. 1992, 157, 452-462. [PubMed]

102. Ozer, P. Dust in the wind and public health: Example from Mauritania. In Desertification: Migration, Health, Remediation and Local Governance; Royal Academy for Overseas Sciences: Brussels, Belgium, 2008; pp. 55-74.

103. Meng, Z.; Lu, B. Dust events as a risk factor for daily hospitalization for respiratory and cardiovascular diseases in Minqin, China. Atmos. Environ. 2007, 41, 7048-7058. [CrossRef]

104. Cheng, M.F.; Ho, S.C.; Chiu, H.F.; Wu, T.N.; Chen, P.S.; Yang, C.Y. Consequences of exposure to Asian dust storm events on daily pneumonia hospital admissions in Taipei, Taiwan. J. Toxicol. Environ. Health Part A 2008, 71, 1295-1299. [CrossRef] [PubMed]

105. Kang, J.H.; Keller, J.J.; Chen, C.S.; Lin, H.C. Asian dust storm events are associated with an acute increase in pneumonia hospitalization. Ann. Epidemiol. 2012, 22, 257-263. [CrossRef] [PubMed]

106. Gudavalli, R.; Garcha, P.; Farver, C.; Yun, J.; Pettersson, G.B.; Mason, D.P.; Murthy, S.P.; Budev, M. Interstitial lung disease associated with Asian dust storm exposure. CHEST J. 2009, 136, 33S-34S. [CrossRef]

107. Chiu, H.F.; Tiao, M.M.; Ho, S.C.; Kuo, H.W.; Wu, T.N.; Yang, C.Y. Effects of Asian dust storm events on hospital admissions for chronic obstructive pulmonary disease in Taipei, Taiwan. Inhal. Toxicol. 2008, 20, 777-781. [CrossRef] [PubMed]

108. Chan, C.C.; Chuang, K.J.; Chen, W.J.; Chang, W.T.; Lee, C.T.; Peng, C.M. Increasing cardiopulmonary emergency visits by long-range transported Asian dust storms in Taiwan. Environ. Res. 2008, 106, 393-400. [CrossRef] [PubMed]

109. Vodonos, A.; Friger, M.; Katra, I.; Avnon, L.; Krasnov, H.; Koutrakis, P.; Schwartz, J.; Lior, O.; Novack, V. The impact of desert dust exposures on hospitalizations due to exacerbation of chronic obstructive pulmonary disease. Air Qual. Atmos. Health 2014, 7, 433-439. [CrossRef]

110. Kim, C.S.; Hu, S.C. Regional deposition of inhaled particles in human lungs: Comparison between men and women. J. Appl. Physiol. 1998, 84, 1834-1844. [PubMed]

111. Seaton, A.; Godden, D.; MacNee, W.; Donaldson, K. Particulate air pollution and acute health effects. Lancet 1995, 345, 176-178. [CrossRef]

112. Gwack, J.; Hwang, S.S.; Kwon, H.J.; Hong, Y.C.; Cho, S.H.; Yoo, Y.; Yoo, J.H.; Ko, Y.R. Effects of Asian dust events on diurnal variation of peak expiratory flow rate in children with bronchial asthma and healthy children. Epidemiology 2005, 16, S109-S110. [CrossRef]

113. Park, J.W.; Lim, Y.H.; Kyung, S.Y.; An, C.H.; Lee, S.P.; Jeong, S.H.; Ju, Y.S. Effects of ambient particulate matter on peak expiratory flow rates and respiratory symptoms of asthmatics during Asian dust periods in Korea. Respirology 2005, 10, 470-476. [CrossRef] [PubMed]

114. Yoo, Y.; Choung J, T.; Yu, J.; Kim, D.K.; Koh, Y.Y. Acute effects of Asian dust events on respiratory symptoms and peak expiratory flow in children with mild asthma. J. Korean Med. Sci. 2008, 23, 66-71. [CrossRef] [PubMed]

115. Hong, Y.C.; Pan, X.C.; Kim, S.Y.; Park, K.; Park, E.J.; Jin, X.; Yi, S.M.; Kim, Y.H.; Park, C.H.; Song, S.; et al. Asian dust storm and pulmonary function of school children in Seoul. Sci. Total Environ. 2010, 408, 754-759. [CrossRef] [PubMed]

116. Kelsall, H.L.; Sim, M.R.; Forbes, A.B.; McKenzie, D.P.; Glass, D.C.; Ikin, J.F.; Ittak, P.; Abramson, M.J. Respiratory health status of Australian veterans of the 1991 Gulf War and the effects of exposure to oil fire smoke and dust storms. Thorax 2004, 59, 897-903. [CrossRef] [PubMed]

117. Derbyshire, E. Natural minerogenic dust and human health. AMBIO: J. Hum. Environ. 2007, 36, 73-77. [CrossRef] 
118. Richards, A.L.; Hyams, K.C.; Watts, D.M.; Rozmajzl, P.J.; Woody, J.N.; Merrell, B.R. Respiratory disease among military personnel in Saudi Arabia during Operation Desert Shield. Am. J. Public Health 1993, 83, 1326-1329. [CrossRef] [PubMed]

119. Crum, N.F.; Potter, M.; Pappagianis, D. Seroincidence of coccidioidomycosis during military desert training exercises. J. Clin. Microbiol. 2004, 42, 4552-4555. [CrossRef] [PubMed]

120. Korzeniewski, K.; Nitsch-Osuch, A.; Chciałowski, A.; Korsak, J. Environmental factors, immune changes and respiratory diseases in troops during military activities. Respir. Physiol. Neurobiol. 2013, 187, 118-122. [CrossRef] [PubMed]

121. Engelbrecht, J.P.; McDonald, E.V.; Gillies, J.A.; Gertler, A.W. Department of Defense Enhanced Particulate Matter Surveillance Program (EPMSP). Available online: http://oai.dtic.mil/oai/oai?verb=getRecord\& metadataPrefix=html\&identifier=ADA605600 (accessed on 25 November 2016).

122. Szema, A.M.; Peters, M.C.; Weissinger, K.M.; Gagliano, C.A.; Chen, J.J. New-onset asthma among soldiers serving in Iraq and Afghanistan. In Allergy and Asthma Proceedings; OceanSide Publications: Rhode Island, RI, USA, 2010; pp. 67-71.

123. King, M.S.; Eisenberg, R.; Newman, J.H.; Tolle, J.J.; Harrell, F.E.; Nian, H.; Ninan, M.; Lambright, E.S.; Scheller, J.R.; Johnson, J.E.; et al. Constrictive bronchiolitis in soldiers returning from Iraq and Afghanistan. N. Engl. J. Med. 2011, 365, 222-230. [CrossRef] [PubMed]

124. Morris, M.J.; Dodson, D.W.; Lucero, P.F.; Haislip, G.D.; Gallup, R.A.; Nicholson, K.L.; Zacher, L.L. Study of active duty military for pulmonary disease related to environmental deployment exposures (STAMPEDE). Am. J. Respir. Crit. Care Med. 2014, 190, 77-84. [CrossRef] [PubMed]

125. Matsumoto, H.; Tabuena, R.P.; Niimi, A.; Inoue, H.; Ito, I.; Yamaguchi, M.; Otsuka, K.; Takeda, T.; Oguma, T.; Nakaji, H.; et al. Cough triggers and their pathophysiology in patients with prolonged or chronic cough. Allergol. Int. 2012, 61, 123-132. [CrossRef] [PubMed]

126. Higashi, T.; Kambayashi, Y.; Ohkura, N.; Fujimura, M.; Nakanishi, S.; Yoshizaki, T.; Saijoh, K.; Hayakawa, K.; Kobayashi, F.; Michigami, Y.; et al. Exacerbation of daily cough and allergic symptoms in adult patients with chronic cough by Asian dust: A hospital-based study in Kanazawa. Atmos. Environ. 2014, 97, 537-543. [CrossRef]

127. Higashi, T.; Kambayashi, Y.; Ohkura, N.; Fujimura, M.; Nakai, S.; Honda, Y.; Saijoh, K.; Hayakawa, K.; Kobayashi, F.; Michigami, Y.; et al. Effects of Asian dust on daily cough occurrence in patients with chronic cough: A panel study. Atmos. Environ. 2014, 92, 506-513. [CrossRef]

128. Yanagisawa, R.; Takano, H.; Ichinose, T.; Mizushima, K.; Nishikawa, M.; Mori, I.; Inoue, K.I.; Sadakane, K.; Yoshikawa, T. Gene expression analysis of murine lungs following pulmonary exposure to Asian sand dust particles. Exp. Biol. Med. 2007, 232, 1109-1118. [CrossRef] [PubMed]

129. Taylor, K.; Foster, M.L.; Law, J.M.H.; Centeno, J.A.; Fornero, E.; Henderson, M.S.; Trager, S.A.; Stockelman, M.G.; Dorman, D.C. Assessment of geographical variation in the respiratory toxicity of desert dust particles. Inhal. Toxicol. 2013, 25, 405-416. [CrossRef] [PubMed]

130. Li, X.; Feng, L.; Huang, C.; Yan, X.; Zhang, X. Potential hazardous elements (PHEs) in atmospheric particulate matter (APM) in the south of Xi'an during the dust episodes of 2001-2012 (NW China): Chemical fractionation, ecological and health risk assessment. Environ. Earth Sci. 2014, 71, 4115-4126. [CrossRef]

131. Naota, M.; Mukaiyama, T.; Shimada, A.; Kohara, Y.; Morita, T.; Inoue, K.; Takano, H. Pathological study of acute pulmonary toxicity induced by intratracheally instilled Asian sand dust (Kosa). Toxicol. Pathol. 2010, 38, 1099-1110. [CrossRef] [PubMed]

132. Honda, A.; Matsuda, Y.; Murayama, R.; Tsuji, K.; Nishikawa, M.; Koike, E.; Yoshida, S.; Ichinose, T.; Takano, H. Effects of Asian sand dust particles on the respiratory and immune system. J. Appl. Toxicol. 2014, 34, 250-257. [CrossRef] [PubMed]

133. Watanabe, M.; Kurai, J.; Tomita, K.; Sano, H.; Abe, S.; Saito, R.; Minato, S.; Igishi, T.; Burioka, N.; Sako, T.; et al. Effects on asthma and induction of interleukin- 8 caused by Asian dust particles collected in western Japan. J. Asthma 2014, 51, 595-602. [CrossRef] [PubMed]

134. He, M.; Ichinose, T.; Yoshida, S.; Nishikawa, M.; Mori, I.; Yanagisawa, R.; Takano, H.; Inoue, K.; Sun, G.; Shibamoto, T. Airborne Asian sand dust enhances murine lung eosinophilia. Inhal. Toxicol. 2010, 22, 1012-1025. [CrossRef] [PubMed] 
135. Kang, I.G.; Jung, J.H.; Kim, S.T. Asian sand dust enhances allergen-induced Th2 allergic inflammatory changes and mucin production in BALB/c mouse lungs. Allergy Asthma Immunol. 2012, 4, 206-213. [CrossRef] [PubMed]

136. He, M.; Ichinose, T.; Yoshida, S.; Takano, H.; Nishikawa, M.; Sun, G.; Shibamoto, T. Induction of immune tolerance and reduction of aggravated lung eosinophilia by co-exposure to Asian sand dust and ovalbumin for 14 weeks in mice. Allerg. Asthma Clin. Immunol. 2013, 9, 19-29. [CrossRef] [PubMed]

137. Gheybi, M.K.; Movahed, A.M.; Dehdari, R.; Amiri, S.; Khazaei, H.A.; Gooya, M.; Dehbashi, F.; Fatemi, A.; Sovid, N.; Hajiani, G.; et al. Dusty air pollution is associated with an increased risk of allergic diseases in southwestern part of Iran. Iran. J. Allergy Asthma Immunol. 2014, 13, 404. [PubMed]

138. Ichinose, T.; Yoshida, S.; Sadakane, K.; Takano, H.; Yanagisawa, R.; Inoue, K.; Nishikawa, M.; Mori, I.; Kawazato, H.; Yasuda, A.; et al. Effects of asian sand dust, Arizona sand dust, amorphous silica and aluminum oxide on allergic inflammation in the murine lung. Inhal. Toxicol. 2008, 20, 685-694. [CrossRef] [PubMed]

139. Ren, Y.; Ichinose, T.; He, M.; Arashidani, K.; Yoshida, Y.; Yoshida, S.; Nishikawa, M.; Takano, H.; Sun, G.; Shibamoto, T. Aggravation of ovalbumin-induced murine asthma by co-exposure to desert-dust and organic chemicals: An animal model study. Environ. Health 2014, 13, 83. [CrossRef] [PubMed]

140. Gao, J.; Wang, Z.; Wang, S. Toxic effect of desert dust of northwest areas of China on alveolar macrophages of rats. J. Environ. Health 2008, 25, 1056-1058.

141. Kyung, S.Y.; Yoon, J.Y.; Kim, Y.J.; Lee, S.P.; Park, J.W.; Jeong, S.H. Asian dust particles induce TGF- $\beta 1$ via reactive oxygen species in bronchial epithelial cells. Tuberc. Respir. Dis. 2012, 73, 84-92. [CrossRef] [PubMed]

142. He, M.; Ichinose, T.; Song, Y.; Yoshida, Y.; Arashidani, K.; Yoshida, S.; Liu, B.; Nishikawa, M.; Takano, H.; Sun, G. Effects of two Asian sand dusts transported from the dust source regions of Inner Mongolia and northeast China on murine lung eosinophilia. Toxicol. Appl. Pharmacol. 2013, 272, 647-655. [CrossRef] [PubMed]

143. Alcorn, J.F.; Crowe, C.R.; Kolls, J.K. TH17 cells in asthma and COPD. Annu. Rev. Physiol. 2010, 72, 495-516. [CrossRef] [PubMed]

144. Aujla, S.J.; Alcorn, J.F. $\mathrm{T}_{\mathrm{H}} 17$ cells in asthma and inflammation. Biochim. Biophys. Acta (BBA)-Gen. Subj. 2011, 1810, 1066-1079. [CrossRef] [PubMed]

145. Lei, Y.C.; Chan, C.C.; Wang, P.Y.; Lee, C.T.; Cheng, T.J. Effects of Asian dust event particles on inflammation markers in peripheral blood and bronchoalveolar lavage in pulmonary hypertensive rats. Environ. Res. 2004, 95, 71-76. [CrossRef]

146. Yeo, N.K.; Hwang, Y.J.; Kim, S.T.; Kwon, H.J.; Jang, Y.J. Asian sand dust enhances rhinovirus-induced cytokine secretion and viral replication in human nasal epithelial cells. Inhal. Toxicol. 2010, 22, 1038-1045. [CrossRef] [PubMed]

147. Shin, S.H.; Ye, M.K.; Hwang, Y.J.; Kim, S.T. The effect of Asian sand dust-activated respiratory epithelial cells on activation and migration of eosinophils. Inhal. Toxicol. 2013, 25, 633-639. [CrossRef] [PubMed]

148. Higashisaka, K.; Fujimura, M.; Taira, M.; Yoshida, T.; Tsunoda, S.; Baba, T.; Yamaguchi, N.; Nabeshi, H.; Yoshikawa, T.; Nasu, M.; et al. Asian Dust Particles Induce Macrophage Inflammatory Responses via Mitogen-Activated Protein Kinase Activation and Reactive Oxygen Species Production. Available online: http:/ / dx.doi.org/10.1155/2014/856154 (accessed on 25 November 2016).

149. He, M.; Ichinose, T.; Yoshida, S.; Yamamoto, S.; Inoue, K.; Takano, H.; Yanagisawa, R.; Nishikawa, M.; Mori, I.; Sun, G.; et al. Asian sand dust enhances murine lung inflammation caused by Klebsiella pneumoniae. Toxicol. Appl. Pharmacol. 2012, 258, 237-247. [CrossRef] [PubMed]

150. Dorman, D.C.; Mokashi, V.; Wagner, D.J.; Wagner, D.J.; Olabisi, A.O.; Wong, B.A.; Moss, O.R.; Centeno, J.A.; Guandalini, G.; Jackson, D.A.; et al. Biological responses in rats exposed to cigarette smoke and Middle East sand (dust). Inhal. Toxicol. 2012, 24, 109-124. [CrossRef] [PubMed]

151. Ghio, A.J.; Kummarapurugu, S.T.; Tong, H.; Soukup, J.M.; Dailey, L.A.; Boykin, E.; Ian Gilmour, M.; Ingram, P.; Roggli, V.L.; Goldstein, H.L.; et al. Biological effects of desert dust in respiratory epithelial cells and a murine model. Inhal. Toxicol. 2014, 26, 299-309. [CrossRef] [PubMed]

152. Krewski, D.; Yokel, R.A.; Nieboer, E.; Borchelt, D.; Cohen, J.; Harry, J.; Kacew, S.; Lindsay, J.; Mahfouz, A.M.; Rondeau, V. Human health risk assessment for aluminium, aluminium oxide, and aluminium hydroxide. J. Toxicol. Environ. Health Part B 2007, 10, 1-269. [CrossRef] [PubMed] 
153. Barnes, P.J.; Celli, B.R. Systemic manifestations and comorbidities of COPD. Eur. Respir. J. 2009, 33, $1165-1185$. [CrossRef] [PubMed]

154. Ezzie, M.E.; Crawford, M.; Cho, J.H.; Orellana, R.; Zhang, S.; Gelinas, R.; Batte, K.; Yu, L.; Nuovo, G.; Galas, D.; et al. Gene expression networks in COPD: MicroRNA and mRNA regulation. Thorax 2011. [CrossRef] [PubMed]

155. Marjanović, N.; Bosnar, M.; Michielin, F.; Willé, D.R.; Anić-Milić, T.; Culić, O.; Popović-Grle, S.; Bogdan, M.; Parnham, M.J.; Eraković Haber, V. Macrolide antibiotics broadly and distinctively inhibit cytokine and chemokine production by COPD sputum cells in vitro. Pharmacol. Res. 2011, 63, 389-397. [CrossRef] [PubMed]

156. Brusselle, G.G.; Joos, G.F.; Bracke, K.R. New insights into the immunology of chronic obstructive pulmonary disease. Lancet 2011, 378, 1015-1026. [CrossRef]

157. Meng, Z.; Zhang, Q. Damage effects of dust storm $\mathrm{PM}_{2.5}$ on DNA in alveolar macrophages and lung cells of rats. Food Chem. Toxicol. 2007, 45, 1368-1374. [CrossRef] [PubMed]

158. Alessandrini, E.R.; Stafoggia, M.; Faustini, A.; Gobbi, G.P.; Forastiere, F. Saharan dust and the association between particulate matter and daily hospitalisations in Rome, Italy. Occup. Environ. Med. 2013. [CrossRef] [PubMed]

159. Zhang, Q.; Zhang, J.; Yang, Z.; Zhang, Y.; Meng, Z. Impact of $\mathrm{PM}_{2.5}$ derived from dust events on daily outpatient numbers for respiratory and cardiovascular diseases in Wuwei, China. Procedia Environ. Sci. 2013, 18, 290-298. [CrossRef]

160. Tam, W.W.; Wong, T.W.; Wong, A.H. Effect of dust storm events on daily emergency admissions for cardiovascular diseases. Circ. J. 2012, 76, 655-660. [CrossRef] [PubMed]

161. Yang, C.Y.; Cheng, M.H.; Chen, C.C. Effects of Asian dust storm events on hospital admissions for congestive heart failure in Taipei, Taiwan. J. Toxicol. Environ. Health Part A 2009, 72, 324-328. [CrossRef] [PubMed]

162. Matsukawa, R.; Michikawa, T.; Ueda, K.; Nitta, H.; Kawasaki, T.; Tashiro, H.; Mohri, M.; Yamamoto, Y. Desert dust is a risk factor for the incidence of acute myocardial infarction in Western Japan. Circ.: Cardiovasc. Qual. Outcomes 2014, 7, 743-748. [CrossRef] [PubMed]

163. Yang, C.Y.; Chen, Y.S.; Chiu, H.F.; Goggins, W.B. Effects of Asian dust storm events on daily stroke admissions in Taipei, Taiwan. Environ. Res. 2005, 99, 79-84. [CrossRef] [PubMed]

164. Kang, J.H.; Liu, T.C.; Keller, J.; Lin, H.C. Asian dust storm events are associated with an acute increase in stroke hospitalisation. J. Epidemiol. Community Health 2012. [CrossRef] [PubMed]

165. Kamouchi, M.; Ueda, K.; Ago, T.; Nitta, H.; Kitazono, T.; Fukuoka stroke registry investigators. Relationship between Asian dust and ischemic stroke a time-stratified case-crossover study. Stroke 2012, 43, 3085-3087. [CrossRef] [PubMed]

166. Wei, A.; Meng, Z. Evaluation of micronucleus induction of sand dust storm fine particles $\left(\mathrm{PM}_{2.5}\right)$ in human blood lymphocytes. Environ. Toxicol. Pharmacol. 2006, 22, 292-297. [CrossRef] [PubMed]

167. Lipsett, M.J.; Tsai, F.C.; Roger, L.; Woo, M.; Ostro, B.D. Coarse particles and heart rate variability among older adults with coronary artery disease in the Coachella Valley, California. Environ. Health Perspect. 2006, 114, 1215-1220. [CrossRef] [PubMed]

168. Chang, C.C.; Hwang, J.S.; Chan, C.C.; Wang, P.Y.; Cheng, T.J. Effects of concentrated ambient particles on heart rate, blood pressure, and cardiac contractility in spontaneously hypertensive rats during a dust storm event. Inhal. Toxicol. 2007, 19, 973-978. [CrossRef] [PubMed]

169. Brook, R. Cardiovascular effects of air pollution. Clin. Sci. 2008, 115, 175-187. [CrossRef] [PubMed]

170. Šrám, R.J.; Binková, B.; Dejmek, J.; Bobak, M. Ambient air pollution and pregnancy outcomes: A review of the literature. Environ. Health Perspect. 2005, 113, 375-382. [CrossRef] [PubMed]

171. Shah, P.S.; Balkhair, T. Air pollution and birth outcomes: A systematic review. Environ. Int. 2011, 37, 498-516. [CrossRef] [PubMed]

172. Stieb, D.M.; Chen, L.; Eshoul, M.; Judek, S. Ambient air pollution, birth weight and preterm birth: A systematic review and meta-analysis. Environ. Res. 2012, 117, 100-111. [CrossRef] [PubMed]

173. Hyder, A.; Lee, H.J.; Ebisu, K.; Koutrakis, P.; Belanger, K.; Bell, M.L. PM 2.5 exposure and birth outcomes: Use of satellite-and monitor-based data. Epidemiology 2014, 25, 58-67. [CrossRef] [PubMed]

174. Dadvand, P.; Basagaña, X.; Figueras, F.; Amoly, E.; Tobias, A.; de Nazelle, A.; Querol, X.; Sunyer, J.; Nieuwenhuijsen, M.J. Saharan dust episodes and pregnancy. J. Environ. Monit. 2011, 13, 3222-3228. [CrossRef] [PubMed] 
175. Yoshida, S.; Hiyoshi, K.; Ichinose, T.; Nishikawa, M.; Takano, H.; Sugawara, I.; Takeda, K. Aggravating effect of natural sand dust on male reproductive function in mice. Reprod. Med. Biol. 2009, 8, 151-156. [CrossRef]

176. Yang, C.Y. Effects of Asian dust storm events on daily clinical visits for conjunctivitis in Taipei, Taiwan. J. Toxicol. Environ. Health Part A 2006, 69, 1673-1680. [CrossRef] [PubMed]

177. Mimura, T.; Yamagami, S.; Fujishima, H.; Noma, H.; Kamei, Y.; Goto, M.; Kondo, A.; Matsubara, M. Sensitization to Asian dust and allergic rhinoconjunctivitis. Environ. Res. 2014, 132, 220-225. [CrossRef] [PubMed]

178. Al-Hurban, A.E.; Al-Ostad, A.N. Textural characteristics of dust fallout and potential effect on public health in Kuwait City and suburbs. Environ. Earth Sci. 2010, 60, 169-181. [CrossRef]

179. Formenti, P.; Schütz, L.; Balkanski, Y.; Desboeufs, K.; Ebert, M.; Kandler, K.; Petzold, A.; Scheuvens, D.; Weinbruch, S.; Zhang, D. Recent progress in understanding physical and chemical properties of African and Asian mineral dust. Atmos. Chem. Phys. 2011, 11, 8231-8256. [CrossRef]

180. Formenti, P.; Caquineau, S.; Desboeufs, K.; Klaver, A.; Chevaillier, S.; Journet, E.; Rajot, J.L. Mapping the physico-chemical properties of mineral dust in western Africa: Mineralogical composition. Atmos. Chem. Phys. 2014, 14, 10663-10686. [CrossRef]

181. Zhang, X.L.; Wu, G.J.; Zhang, C.L.; Xu, T.L.; Zhou, Q.Q. What is the real role of iron oxides in the optical properties of dust aerosols? Atmos. Chem. Phys. 2015, 15, 12159-12177. [CrossRef]

182. Otani, S.; Onishi, K.; Mu, H.; Kurozawa, Y. The effect of Asian dust events on the daily symptoms in Yonago, Japan: A pilot study on healthy subjects. Arch. Environ. Occup. Health 2011, 66, 43-46. [CrossRef] [PubMed]

183. Otani, S.; Onishi, K.; Mu, H.; Yokoyama, Y.; Hosoda, T.; Okamoto, M.; Kurozawa, Y. The relationship between skin symptoms and allergic reactions to Asian dust. Int. J. Environ. Res. Public Health 2012, 9, 4606-4614. [CrossRef] [PubMed]

184. Onishi, K.; Otani, S.; Yoshida, A.; Mu, H.; Kurozawa, Y. Adverse health effects of Asian dust particles and heavy metals in Japan. Asia-Pac. J. Public Health 2012, 27, 1719-1726. [CrossRef] [PubMed]

185. Onishi, K.; Kurosaki, Y.; Otani, S.; Yoshida, A.; Sugimoto, N.; Kurozawa, Y. Atmospheric transport route determines components of Asian dust and health effects in Japan. Atmos. Environ. 2012, 49, 94-102. [CrossRef]

186. Choi, H.; Shin, D.W.; Kim, W.; Doh, S.J.; Lee, S.H.; Noh, M. Asian dust storm particles induce a broad toxicological transcriptional program in human epidermal keratinocytes. Toxicol. Lett. 2011, 200, 92-99. [CrossRef] [PubMed]

187. Zhou, J.; Zhao, X.G.; Wang, Q. Effects of dust event on the upper respiratory tract and eyes uncomfortable symptoms of primary school students in Southern Xinjiang. J. Environ. Health 2010, 27, 767-771.

188. Mu, H.; Battsetseg, B.; Ito, T.Y.; Otani, S.; Onishi, K.; Kurozawa, Y. Health effects of dust storms: Subjective eye and respiratory system symptoms in inhabitants in Mongolia. J. Environ. Health 2011, 73, 18-20. [PubMed]

189. Doganay, H.; Akcali, D.; Goktaş, T.; Caglar, K.; Erbas, D.; Saydam, C.; Bolay, H. African dust-laden atmospheric conditions activate the trigeminovascular system. Cephalalgia 2009, 29, 1059-1068. [CrossRef] [PubMed]

190. Kellogg, C.A.; Griffin, D.W. Aerobiology and the global transport of desert dust. Trends Ecol. Evol. 2006, 21, 638-644. [CrossRef] [PubMed]

191. Griffin, D.W.; Kellogg, C.A. Dust storms and their impact on ocean and human health: Dust in Earth's atmosphere. EcoHealth 2004, 1, 284-295. [CrossRef]

192. Leski, T.A.; Malanoski, A.P.; Gregory, M.J.; Lin, B.; Stenger, D.A. Application of broad-range resequencing array RPM-TEI for detection of pathogens in desert dust samples from Kuwait and Iraq. Appl. Environ. Microbiol. 2011. [CrossRef] [PubMed]

193. Malo, J.; Luraschi-Monjagatta, C.; Wolk, D.M.; Thompson, R.; Hage, C.A.; Knox, K.S. Update on the diagnosis of pulmonary coccidioidomycosis. Ann. Am. Thorac. Soc. 2014, 11, 243-253. [CrossRef] [PubMed]

194. Kolivras, K.N.; Johnson, P.S.; Comrie, A.C.; Yool, S.R. Environmental variability and coccidioidomycosis (valley fever). Aerobiologia 2001, 17, 31-42. [CrossRef]

195. Nguyen, C.; Barker, B.M.; Hoover, S.; Nix, DE.; Ampel, N.M.; Frelinger, J.A.; Orbach, M.J.; Galgiani, J.N. Recent advances in our understanding of the environmental, epidemiological, immunological, and clinical dimensions of coccidioidomycosis. Clin. Microbiol. Rev. 2013, 26, 505-525. [CrossRef] [PubMed]

196. Thomson, M.C.; Connor, S.J.; Ward, N.; Molyneux, D. Impact of climate variability on infectious disease in West Africa. EcoHealth 2004, 1, 138-150. [CrossRef] 
197. Sultan, B.; Labadi, K.; Guégan, J.F.; Janicot, S. Climate drives the meningitis epidemics onset in West Africa. PLoS Med 2005, 2, e6. [CrossRef] [PubMed]

198. Yaka, P.; Sultan, B.; Broutin, H.; Janicot, S.; Philippon, S.; Fourquet, N. Relationships between climate and year-to-year variability in meningitis outbreaks: A case study in Burkina Faso and Niger. Int. J. Health Geogr. 2008, 7, 34. [CrossRef] [PubMed]

199. Thomson, M.C.; Jeanne, I.; Djingarey, M. Dust and epidemic meningitis in the Sahel: A public health and operational research perspective. In IOP Conference Series: Earth and Environmental Science; IOP: Barcelona, Spain, 2009; Volume 7. [CrossRef]

200. Dukić, V.; Hayden, M.; Forgor, A.A.; Hopson, T.; Akweongo, P.; Hodgson, A.; Monaghan, A.; Wiedinmyer, C.; Yoksas, T.; Thomson, M.C.; et al. The role of weather in meningitis outbreaks in Navrongo, Ghana: A generalized additive modeling approach. J. Agric. Biol. Environ. Stat. 2012, 17, 442-460. [CrossRef]

201. Molesworth, A.M.; Cuevas, L.E.; Connor, S.J.; Morse, A.P.; Thomson, M.C. Environmental risk and meningitis epidemics in Africa. Emerg. Infect. Dis. 2003, 9, 1287. [CrossRef] [PubMed]

202. Tobías, A.; Caylà J, A.; Pey, J.; Alastuey, A.; Querol, X. Are Saharan dust intrusions increasing the risk of meningococcal meningitis? Int. J. Infectious Dis. 2011, 15, e503. [CrossRef] [PubMed]

203. Agier, L.; Deroubaix, A.; Martiny, N.; Yaka, P.; Djibo, A.; Broutin, H. Seasonality of meningitis in Africa and climate forcing: Aerosols stand out. J. R. Soc. Interface 2013, 10, 20120814. [CrossRef] [PubMed]

204. Martiny, N.; Chiapello, I. Assessments for the impact of mineral dust on the meningitis incidence in West Africa. Atmos. Environ. 2013, 70, 245-253. [CrossRef]

205. Deroubaix, A.; Martiny, N.; Chiapello, I.; Marticoréna, B. Suitability of OMI aerosol index to reflect mineral dust surface conditions: Preliminary application for studying the link with meningitis epidemics in the Sahel. Remote Sens. Environ. 2013, 133, 116-127. [CrossRef]

206. Pérez, G.P.C.; Stanton, M.C.; Diggle, P.J.; Trzaska, S.; Miller, R.L.; Perlwitz, J.P.; Baldasano, J.M.; Cuevas, E.; Ceccato, P.; Yaka, P.; et al. Soil dust aerosols and wind as predictors of seasonal meningitis incidence in Niger. Environ. Health Perspect. 2014, 122, 679-696.

207. Jordan, P.W.; Saunders, N.J. Host iron binding proteins acting as niche indicators for Neisseria meningitidis. PLoS ONE 2009, 4, e5198. [CrossRef] [PubMed]

208. Meningitis Belt over North Africa, the Meningitis Vaccine Project. Available online: http:/ www.meningvax.org (accessed on 25 November 2016). 